\title{
Complementary research models and methods to study axonal regeneration in the vertebrate retinofugal system
}

\author{
Ilse Bollaerts ${ }^{1}$ (D) Lien Veys $^{1} \cdot$ Emiel Geeraerts $^{1} \cdot$ Lien Andries $^{1} \cdot$ Lies De Groef $^{1,2} \cdot$ Tom Buyens $^{1}$. \\ Manuel Salinas-Navarro ${ }^{1} \cdot$ Lieve Moons $^{1} \cdot$ Inge Van Hove ${ }^{1,2}$
}

Received: 6 July 2017 / Accepted: 15 November 2017 / Published online: 30 November 2017

(c) The Author(s) 2017. This article is an open access publication

\begin{abstract}
Due to the lack of axonal regeneration, age-related deterioration in the central nervous system (CNS) poses a significant burden on the wellbeing of a growing number of elderly. To overcome this regenerative failure and to improve the patient's life quality, the search for novel regenerative treatment strategies requires valuable (animal) models and techniques. As an extension of the CNS, the retinofugal system, consisting of retinal ganglion cells that send their axons along the optic nerve to the visual brain areas, has importantly contributed to the current knowledge on mechanisms underlying the restricted regenerative capacities and to the development of novel strategies to enhance axonal regeneration. It provides an extensively used research tool, not only in amniote vertebrates including rodents, but also in anamniote vertebrates, such as zebrafish. Indeed, the latter show robust regeneration capacities, thereby providing insights into the factors that contribute to axonal regrowth and proper guidance, complementing studies in mammals. This review provides an integrative and critical overview of the classical and state-of-the-art models and methods that have been employed in the retinofugal system to advance our knowledge on the signaling pathways underlying the restricted versus robust axonal regeneration in rodents and zebrafish, respectively. In vitro, ex vivo and in vivo models and techniques to improve the visualization and analysis of regenerating axons are summarized. As such, the retinofugal system is presented as a valuable model to further facilitate research on axonal regeneration and to open novel therapeutic avenues for CNS pathologies.
\end{abstract}

Keywords Optic nerve injury $\cdot$ Rodents $\cdot$ Zebrafish $\cdot$ Axonal regeneration $\cdot$ Visual behavior

$\begin{array}{ll}\text { Abbreviations } \\ \text { BABB } & \text { Benzyl alcohol-benzyl benzoate } \\ \text { BDNF } & \text { Brain derived neurotrophic factor } \\ \text { cAMP } & \text { Cyclic adenosine monophosphate } \\ \text { CFP } & \text { Cyan fluorescent protein } \\ \text { CNS } & \text { Central nervous system } \\ \text { CNTF } & \text { Ciliary neurotrophic factor } \\ \text { CSPG } & \text { Chondroitin sulfate proteoglycan } \\ \text { CTB } & \text { Cholera toxin subunit b } \\ \text { DIC } & \text { Differential interference contrast }\end{array}$

Lieve Moons

Lieve.moons@kuleuven.be

1 Neural Circuit Development and Regeneration Research Group, Animal Physiology and Neurobiology Section, Department of Biology, KU Leuven, Naamsestraat 61, Box 2464, 3000 Leuven, Belgium

2 Laboratory of Ophthalmology, Department of Neurosciences, KU Leuven, 3000 Leuven, Belgium
DiI $\quad 1,1^{\prime}$-Dioctadecyl-3,3,3', $3^{\prime}$ tetramethylindocarbocyanine perchlorate

dLGN Dorsal lateral geniculate nucleus

DLR Dorsal light response

dpi Days post injury

DTI Diffusion tensor magnetic resonance imaging

DREADD Designer receptors exclusively activated by designer drugs

ECM Extracellular matrix

EPI Echo-planar imaging

ER Escape response

GAP43 Growth-associated protein 43

GFAP Glial fibrillary acidic protein

GFP Green fluorescent protein

HRP Horse radish peroxidase

iDISCO Immunolabeling-enabled three-dimensional imaging of solvent-cleared organs

IGF-1 Insulin-like growth factor 1

ipRGC Intrinsically photosensitive retinal ganglion cell 


$\begin{array}{ll}\text { JAK/STAT } & \begin{array}{l}\text { Janus kinase/signal transducers and activa- } \\ \text { tors of transcription }\end{array} \\ \text { LSFM } & \begin{array}{l}\text { Light sheet fluorescence microscopy } \\ \text { Myelin-associated glycoprotein }\end{array} \\ \text { MAG } & \begin{array}{l}\text { Manganese-enhanced magnetic resonance } \\ \text { MEMaging }\end{array} \\ \text { MRI } & \text { Magnetic resonance imaging } \\ \text { mTOR } & \text { Mammalian target of rapamycin } \\ \text { OKR } & \text { Optokinetic response } \\ \text { OMgp } & \text { Oligodendrocyte myelin glycoprotein } \\ \text { OMR } & \text { Optomotor response } \\ \text { ONC } & \text { Optic nerve crush } \\ \text { ONT } & \text { Optic nerve transection } \\ \text { PNG } & \text { Peripheral nerve graft } \\ \text { PNS } & \text { Peripheral nervous system } \\ \text { PTEN } & \text { Phosphatase and tensin homolog } \\ \text { RITC } & \text { Rhodamine isothiocyanate } \\ \text { RGC } & \text { Retinal ganglion cell } \\ \text { Rheb1 } & \text { Ras homolog enriched in brain 1 } \\ \text { SCN } & \text { Suprachiasmatic nucleus } \\ \text { SOCS3 } & \text { Suppressor of cytokine signaling } 3 \\ \text { Thy1 } & \text { Thymus cell antigen 1 } \\ \text { tuba1a } & \alpha \text {-tubulin1 } \\ \text { V1 } & \text { Primary visual cortex } \\ \text { VEP } & \text { Visually evoked potential } \\ \text { YFP } & \text { Yellow fluorescent protein } \\ & \end{array}$

\section{Introduction}

Neurodegenerative diseases such as Alzheimer's, Parkinson's and Huntington's disease, multiple sclerosis, and glaucoma, as well as ischemic and traumatic central nervous system (CNS) insults, importantly contribute to the most devastating and costly neurological disorders of our society. Indeed, these currently incurable pathologies result in (progressive) neuronal degeneration, with widespread functional deficits such as movement and/or cognitive problems. In addition, since the population is rapidly aging, age-related neurodegenerative diseases are becoming one of the leading medical and social-economic challenges faced by the current society. These pathologies have a large negative impact on healthy life span because the CNS of adult mammals has only a limited capacity to replace lost neurons (i.e. de novo neurogenesis) or to repair damaged axons (i.e. axonal regeneration), the latter being the focus of this review.

Ever since the pioneering work of Ramón y Cajal in the beginning of the twentieth century (Ramón y Cajal and May 1928), the primary visual pathway has been extensively used as a model to study the mechanisms underlying the limited regenerative capacity in the adult CNS. Indeed, the retina and the optic nerve are the most accessible parts of the CNS, and have a well-characterized and conserved morphology and function (Benowitz and Yin 2007; London et al. 2013).

As already observed by Cajal, damaged axons in the mammalian optic nerve show transient sprouting, but this response is abortive and does not result in long-range growth (Ramón y Cajal and May 1928). Yet, several early studies, including the observation that at least some retinal ganglion cells (RGCs) are able to regenerate injured axons into a peripheral nerve graft (PNG) (Ramón y Cajal and May 1928; Richardson et al. 1980; David and Aguayo 1981, 1985), suggested that CNS regeneration is being prevented by growth-inhibitory factors, and/or by the lack of growthpromoting factors. In the 1980s, it was discovered that CNS myelin, but not peripheral nervous system (PNS) myelin, is highly suppressive to axonal growth (Schwab and Thoenen 1985; Schwab and Caroni 1988). Today, many growthinhibitory factors of CNS myelin are identified, including the Nogo family, myelin-associated glycoprotein (MAG) and oligodendrocyte-myelin glycoprotein (OMgp). Another extrinsic barrier to growth is the glial scar formed by reactive astrocytes (Filbin 2003; Fischer et al. 2004; Silver and Miller 2004; Benowitz and Yin 2007; Berry et al. 2008; Fitch and Silver 2008; Fischer and Leibinger 2012; London et al. 2013). Overcoming these inhibitory factors, as well as providing trophic support molecules can considerably enhance RGC axonal regeneration (Logan et al. 2006; Berry et al. 2008; Galindo-Romero et al. 2013; Shum et al. 2016). Of the many neurotrophic molecules studied, cytokine ciliary neurotrophic factor (CNTF) has been repeatedly shown to stimulate regeneration of adult RGC axons, and is one of the best neuritogenic factors known so far (Cui and Harvey 2000; Muller et al. 2007; Hellstrom et al. 2011; Pernet et al. 2013a). Here, it has to be noted that there is a clear difference between the pathways that stimulate RGC survival and axonal outgrowth. This is exemplified by the trophic factor brain derived neurotrophic factor (BDNF), which enhances neuronal survival when injected into the vitreous, but has a negative effect on axonal regeneration (Benowitz and Yin 2007; Fischer and Leibinger 2012).

Nevertheless, the axonal outgrowth potential induced via the strategies described above is limited. Therefore, during the last years, more attention goes to stimulation of signaling pathways for intrinsic growth control. It has been shown that the Janus Kinase/Signal Transducers and Activators of Transcription (JAK/STAT) pathway is an important player in optic nerve regeneration, as deletion of its negative inhibitor suppressor of cytokine signaling 3 (SOCS3) markedly improves the regenerative outcome (Smith et al. 2009). Similarly, deletion of phosphatase and tensin homolog (PTEN), an upstream inhibitor of the mammalian target of rapamycin (mTOR) pathway, positively affects the regenerative response (Park et al. 2008). Alterations in these pathways, whether or not combined with the induction of controlled 
ocular inflammation and glial reactivity or other regenerative treatments, result in more robust optic nerve regeneration (Kurimoto et al. 2010, 2013; Sun and He 2010; Benowitz and Popovich 2011; de Lima et al. 2012; Lorber et al. 2012; Benowitz et al. 2017; Leibinger et al. 2016; Lim et al. 2016). Nevertheless, full recovery after CNS injury or in neurodegenerative disorders remains a huge challenge. Indeed, the multifactorial treatments developed today can promote axonal extension, but navigation errors of growing axons are still an unsolved problem. Furthermore, correct synaptogenesis in the target areas, a prerequisite for functional recovery, remains largely unexplored (Luo et al. 2013; Pernet et al. 2013b; Pernet and Schwab 2014).

On the contrary, since Sperry's work in the 1950s, it has been demonstrated that adult teleost fish, as well as other anamniote vertebrates, have the ability to partially or even fully recover from injuries in the CNS, including the retinofugal system (Sperry 1948; Attardi and Sperry 1963). The attempt to discover the mechanisms underlying these species differences in CNS regeneration led to the modern era of regeneration research. It is now well accepted that the remarkable capacity for CNS repair in teleost fish most likely arises from both a high intrinsic growth capacity and a limited inhibitory environment (Becker and Becker 2014). Although early experiments on optic nerve regeneration have been performed mainly in goldfish, the zebrafish gained more attention in recent years and has now become an established model organism to study axonal regeneration (Becker and Becker 2014; Diekmann et al. 2015b). Interestingly, in adult zebrafish subjected to optic nerve injury, RGC axons spontaneously regrow and reconnect with their target neurons in the brain, eventually restoring vision (Becker and Becker 2014).

Within this review, we aim to highlight the current state of models and techniques that have been applied to unravel the mechanisms and signaling pathways underlying restricted or robust axonal outgrowth and regeneration after optic nerve injury. In vitro, ex vivo and in vivo methods to study axonal elongation will be discussed, as well as the most important electrophysiological and behavioral assays for the evaluation of functional recovery.

\section{In vitro models to study axonal outgrowth}

\section{In vitro cellular studies in rodents}

As compared to in vivo animal models of axonal injury, in vitro models are more suitable for efficient screening of axon growth promoting compounds, and have thus provided a significant contribution to the field. These simplified systems with strict control of environmental factors are beneficial in terms of time and cost-savings and often required to gain further insights in findings emerging from in vivo investigations (Koechling et al. 2011). Within the field of in vitro studies, two main approaches can be distinguished: the use of an immortalized cell line, and primary RGC cultures (Goritz et al. 2007; Koriyama et al. 2011; Gupta et al. 2013; Steketee et al. 2014; Sugitani et al. 2016). Immortalized cell lines offer the advantage of easy culturing and rapid growth. RGC-5 cells have been widely used in the past to study the neurobiology of RGCs, but the origin and nature of the cells have been highly debated in more recent years (Krishnamoorthy et al. 2013; Sippl and Tamm 2014). R28 is another cell line of retinal origin, which is less controversial, and mostly used in neuroprotection studies (Seigel 2014).

Importantly, however, transformed cell lines do not necessarily exhibit the same characteristic properties as their cells of origin. It is, therefore, essential to validate findings with biologically more relevant tools such as cultured primary RGCs (as well as with ex vivo and/or in vivo models, see below) (Krishnamoorthy et al. 2013; Sippl and Tamm 2014). In contrast to immortalized cell lines, primary RGCs retain many of their native morphological, neurochemical and electrophysiological properties (Dumanskaya et al. 2011). Culturing of RGCs and subsequent neurite outgrowth has been described for embryonic, newborn, and adult mice and rats. Of note, however, neurites from embryonic RGCs show the fastest outgrowth potential (Goldberg et al. 2002). Interestingly, in postnatal mice, it has been demonstrated that an optic nerve crush (ONC) injury prior to the isolation of RGCs induces more rapid neurite outgrowth as compared to RGCs isolated from naive retinas. The injury may induce increased expression of growth-associated genes in the RGCs, thereby promoting neurite outgrowth in the primed retinas (Wu et al. 2003). Isolation of primary RGCs from a retinal cell suspension can be performed via immunopanning, which is essentially the immunoprecipitation of the cells to a solid surface coated with RGC-specific antibodies such as thymus cell antigen 1 (Thy1). Alternatively, RGCs can be purified via magnetic separation, in which the cells are bound to magnetic beads, again coated with RGC-specific antibodies. Third, purification methods that combine immunopanning with magnetic separation are also in use (Inatani et al. 2001; Wehrwein et al. 2004; Ivanov et al. 2008; Surgucheva et al. 2008; Zhang et al. 2010; Hong et al. 2012, 2014; Gupta et al. 2013; Steketee et al. 2014) (reviewed by Hong et al. 2012; Ghinia 2013). However, obtaining pure RGC cultures with a sufficient number of cells is challenging, especially in mice. Therefore, many researchers switched to the use of mixed retinal (neuronal) cell cultures, which have proven valid to evaluate neurite outgrowth (Luo et al. 2001; Ahmed et al. 2010; Vecino et al. 2015; Morgan-Warren et al. 2016). Importantly, the number of neurites as well as the neurite length is increased in cocultures of RGCs and Müller glia, compared to pure RGC 
cultures (Ruzafa and Vecino 2015). An important advantage of these mixed cultures is the improved survival time and viability of the cells. However, RGCs may constitute only a limited percentage of the total retinal cells in these cultures, compromising the study of specific effects on RGCs (Zhang et al. 2002; Xu et al. 2011).

Neuronal cell cultures can be applied for static or dynamic (time-lapse) follow-up of RGC neurite outgrowth rate and growth cone morphology and dynamics, which can be visualized either via addition of calcein-acetoxymethylester to the culture medium (Inatani et al. 2001; Zhang et al. 2010), via immunostainings for $\beta$-tubulin, $\alpha$-tubulin, $\gamma$-synuclein, neurofilament $68 \mathrm{kDa}$ subunit or Thy-1 (Luo et al. 2001; Surgucheva et al. 2008; Gupta et al. 2013; Hong et al. 2014; Steketee et al. 2014) or using differential interference contrast (DIC) optics (Steketee et al. 2014). Alternatively, transgenic lines where RGCs are fluorescently labeled, such as expression of yellow fluorescent protein (YFP) under the Thy 1 promoter (Thy1-YFP), could also prove valuable. Yet, Thy 1 expression is known to decrease in injured RGCs (Lindsey et al. 2013), and it remains unclear whether the YFP signal remains stable enough for in vitro studies.

Coatings such as laminin, fibronectin, and collagen type I and IV enhance neurite outgrowth from retinal neurons. These extracellular matrix (ECM) molecules are produced by glial cells (as well as by fibroblasts), and it is well known that macroglia/astrocytes are a good substratum and guide for growing neurites, as shown via cultured embryonic retinal neurons grown on astrocyte monolayers (Neugebauer et al. 1988; Ard et al. 1991; Yoshida and Takeuchi 1991). Yet, astrocytes/glia also rapidly react to CNS injuries by changing their morphology and gene expression pattern. This might eventually lead to the formation of a glial scar. Pre-incubating cell culture plates with inhibitory glial scarassociated molecules, such as chondroitin sulfate proteoglycans (CSPGs) or myelin extracts, results in a reduced neurite outgrowth from purified RGCs (Inatani et al. 2001; Ahmed et al. 2009; Bermel et al. 2009). Thus, alternative coatings can be used to investigate the potential of compounds to interfere with or to abrogate the signaling pathways that prevent axonal outgrowth after addition of inhibitory myelin or glial scar-derived molecules (Ahmed et al. 2009; Bermel et al. 2009).

\section{In vitro cellular studies in other vertebrates}

Although the use of non-rodent retinal cells to study neurite outgrowth in vitro is rather uncommon, some early work has been performed in chicken (Brocco and Panzetta 1997, 1999) and goldfish (Cohen et al. 1989; Yazejian and Fain 1993; Schwalb et al. 1995). Notably, an assay to investigate RGC axon outgrowth in dissociated mixed retinal cell cultures from zebrafish eyes was recently developed. Transgenic
$\operatorname{Tg}($ gap 43:GFP) fish, which express green fluorescent protein (GFP) under control of the growth-associated protein 43 (gap43) promoter, resulting in a green fluorescent signal in RGCs only, allowed straightforward identification of these neurons in culture. Moreover, the GFP signal is also present in the growing RGC neurites, facilitating accurate quantification of their growth (Diekmann et al. 2015b).

Conclusively, in vitro setups to study axonal outgrowth are well developed in rodents, and can serve as low cost screening methods for a variety of compounds in a wide range of experimental conditions. In vitro studies in other animals are scarce, but the availability of transgenic zebrafish to label RGCs might open up new avenues, as this model species brings the advantage of spontaneous adult regeneration.

\section{Ex vivo models to study axonal outgrowth and guidance}

\section{Ex vivo tissue explant studies in rodents}

In contrast to the in vitro experiments that employ immortalized cell lines or primary dissociated cell cultures described above, living tissue isolated from the organism can also be brought into culture. This approach is termed 'ex vivo'. Hereby, proper cell-to-cell and cell-ECM interactions are preserved and the 'natural' situation is thus better represented than in in vitro cellular models. Yet, ex vivo tissue explant systems still allow investigation under highly standardized conditions, offering a clear benefit over in vivo research in animal models (see below). In the context of the retinofugal system, retinal organotypic or explant cultures have been extensively used for the identification and validation of novel pro-regenerative substances (Atkinson et al. 1999; Bocker-Meffert et al. 2002; Monnier et al. 2003; Lagreze et al. 2005; Buyens et al. 2014; Gaublomme et al. 2014; Van de Velde et al. 2015). Because of the (partial) resemblance of physiological intercellular processes and communications, they also allow investigating biophysical properties of ion channels in outgrowing axons/growth cones via whole cell, patch clamp recordings (Feigenspan et al. 2010).

Rodent retinal explants are made by manually cutting retinal whole mounts into pieces, using a tissue chopper, or by creating punch biopsies with different diameters (Tsai et al. 1998; Monnier et al. 2003; Sagawa et al. 2007; Bermel et al. 2009; Buyens et al. 2014). The neurites growing out from the retinal explants are assumed to be RGC axons based on the expression of appropriate markers, retrograde labeling, the directionality of emergence from the explant, their axonal morphology, and on the ability to conduct action potentials (Bates and Meyer 1997). Of note, Thy1-YFP mice 
have recently been used to develop an organotypic culture model where RGCs are fluorescently labeled. This line provides a useful tool for time-lapse imaging of the outgrowing neurites (Johnson et al. 2016). Retinal explants can be harvested from embryonic, postnatal or adult eyes, whether or not primed by optic nerve injury. However, similar to what has been described for dissociated RGCs, a striking age-dependent loss in axonal outgrowth ability has been observed (Goldberg and Barres 2000). Retinal explants from adult rodents barely show outgrowing neurites, although their density and length depend on the experimental protocol used. Neurite outgrowth can be induced by adding appropriate growth factors (Ford-Holevinski et al. 1986; Cohen et al. 1994; Liu et al. 2006; Bermel et al. 2009; Gasparini et al. 2011), or using explants from eyes primed via optic nerve injury (Tsai et al. 1998).

Similar to studies on dissociated cells, retinal explants can be applied to explore whether a compound of interest supports axonal outgrowth by interacting with a nonpermissive environment, by breaking down the glial scar and/or by degrading myelin debris or other inhibitory/ repellent molecules, more specifically by adding molecules such as myelin extracts or CSPGs to the growth substratum (Monnier et al. 2003; Ahmed et al. 2009; Bermel et al. 2009). Interestingly, axonal guidance, modulated by growth cones at their distal tip, can easily be studied by culturing explants on striped patterns of bio-active molecules. Using these stripe assays and evaluating the response of growing axons to these molecules, novel guidance molecules have been identified (Drescher et al. 1995; Monnier et al. 2002, 2003; Knoll et al. 2007). Another assay to identify axonal attractants or repellents is the growth cone collapse assay, in which isolated axons are confronted with target-derived membranes or purified proteins under study and changes in growth cone morphology and growth direction are assessed (Drescher et al. 1995; Monnier et al. 2002; Cook et al. 2014).

Our research group recently established a postnatal murine retinal explant model to study axonal outgrowth (Gaublomme et al. 2013; Buyens et al. 2014; Van de Velde et al. 2015; Van Hove et al. 2015). This model is based on a previously described rat explant model, in which retinas from rat pups of 10 days old (postnatal day 10, P10) were used and neurite outgrowth was quantified after 3 days in culture (Lagreze et al. 2005). As we found that neurite outgrowth decreases rapidly after birth and may also become more variable (Fig. 1), conform previous reports (Goldberg et al. 2002), we have used retinal explants from mice at day of birth (P0) or P3, to obtain a better and more consistent neurite outgrowth profile. Axonal outgrowth from explants can easily be visualized via immunostaining for the axonal marker $\beta$-tubulin, and automatically quantified as previously described (Gaublomme et al. 2013; Van de Velde et al.
Fig. 1 Comparison of neurite outgrowth from mouse retinal explants at different ages. Mouse retinal explants were dissected at postnatal day $0(\mathrm{P} 0$, day of birth) (a), P3 (b) and P7 (c) and their neurite outgrowth was quantified after $72 \mathrm{~h}$ using a $\beta$-tubulin immunostaining. P0 retinal explants showed significantly more neurite outgrowth as compared to explants harvested at P3 and P7. No significant difference in neurite outgrowth was observed between P3 and P7 explants. Data are represented as mean \pm SEM, $\mathrm{P} 0$ neurite outgrowth was set at $100 \%$. $* * p<0.01$ compared to $\mathrm{P} 0, n \geq 21$ (d)
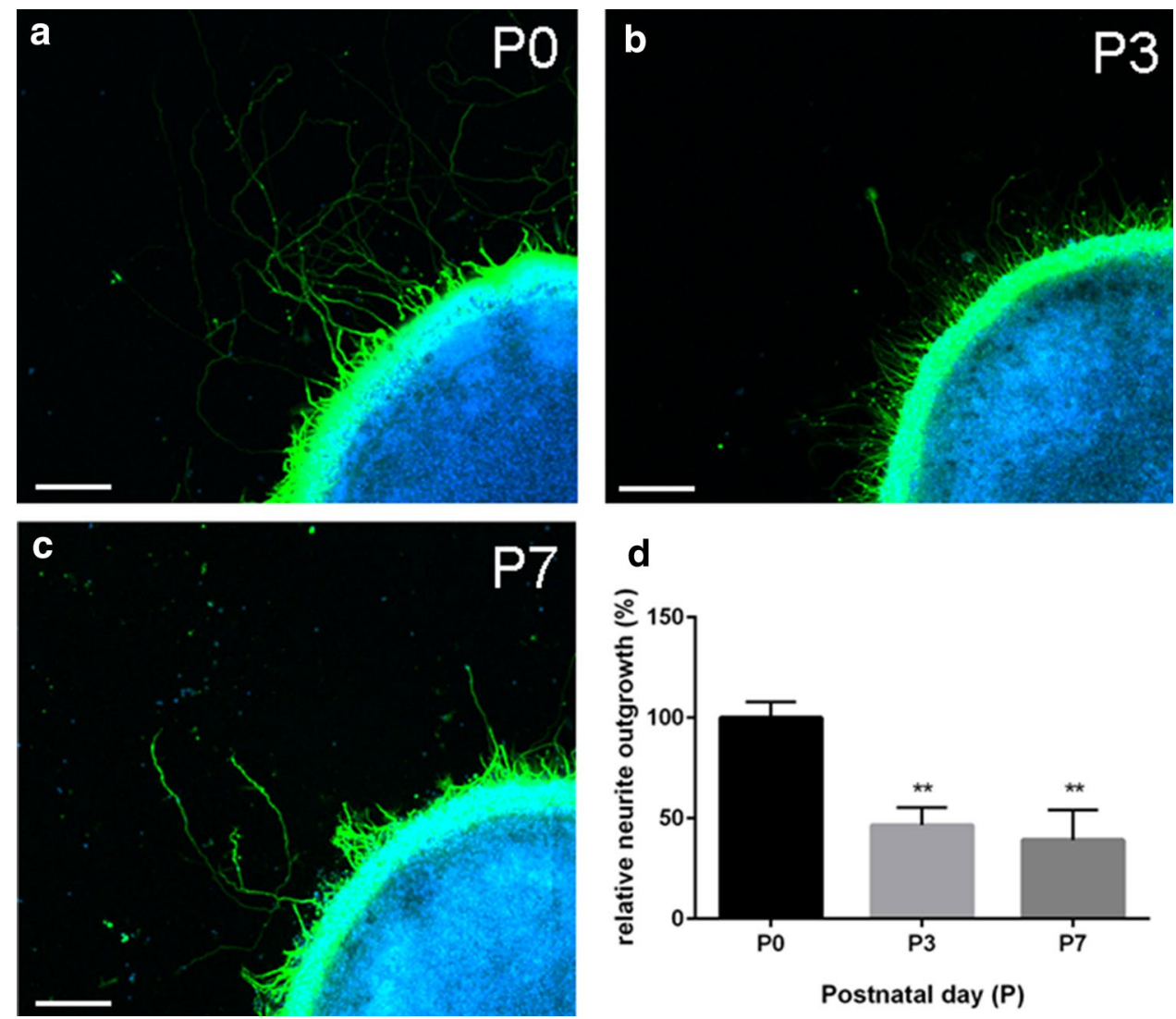


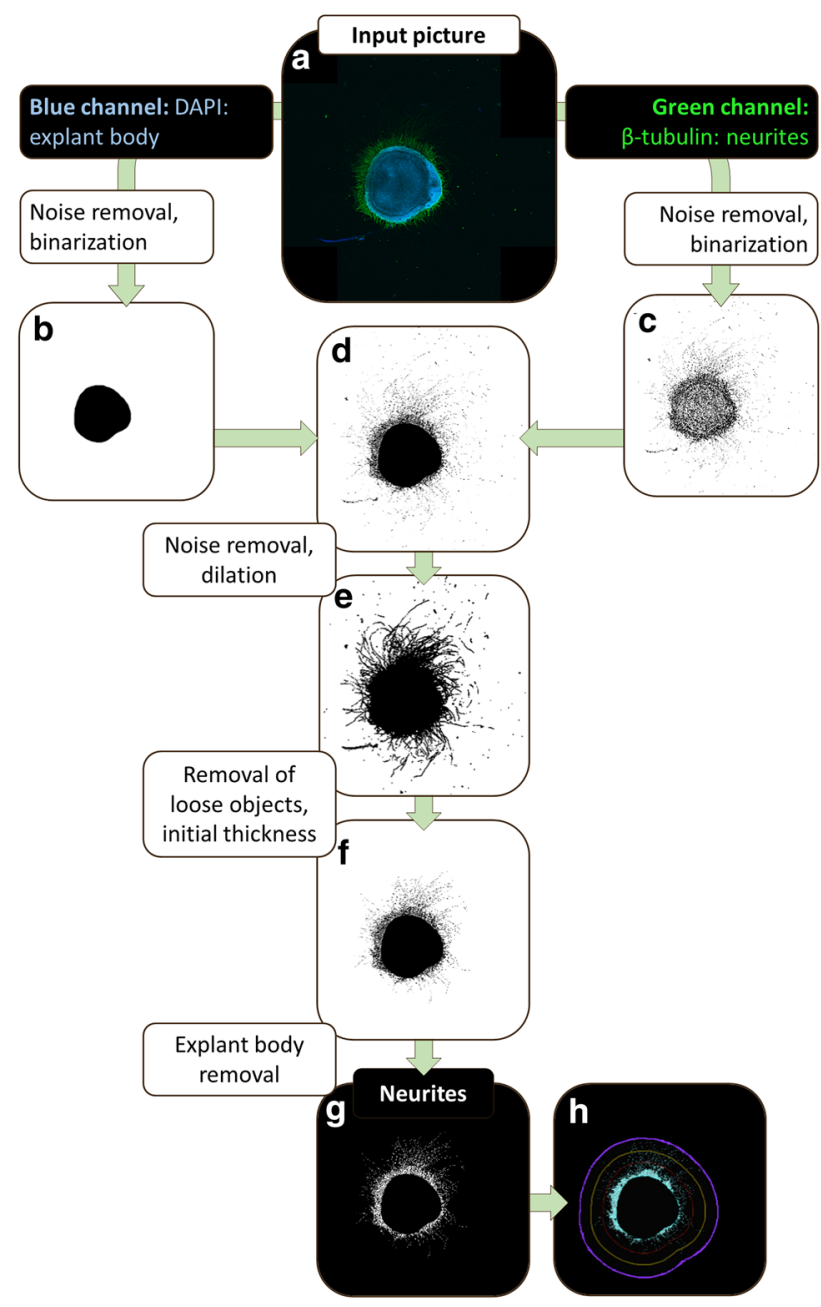

Fig. 2 Main steps in the ImageJ script for optimal automated neurite outgrowth assessment. Explant picture with in blue the DAPI positive explant body and in green the $\beta$-tubulin immunopositive neurites (a). Binarized and processed (noise removal and smoothing edges) picture of the blue and green channel $(\mathbf{b}, \mathbf{c})$. Pictures from $\mathbf{b}$ and $\mathbf{c}$ are merged in $\mathbf{d}$ (d). In order to account for staining and imaging imperfections that can cause small gaps between two neurite pieces, neurites are dilated to bridge small gaps after a noise removal step (e). Particles unattached to the explant body are removed and neurites are returned to their initial thickness (f). After removal of the explant body, only the outgrowing neurites remain, with an optimal signal to noise ratio (g). This neurite picture is divided into four segments by drawing three concentric circles, each $100 \mu \mathrm{m}$ further from the explant body. Quantifying the neurite outgrowth area in these segments makes distinction between neurite outgrowth initiation (closer to the explant body) and neurite elongation (further from the explant body) possible (h)

2015), or using an ImageJ script, such as the one developed in our laboratory (Fig. 2). These scripts allow for fast detection of neurite outgrowth, with the possibility to distinguish between neurite outgrowth initiation and neurite elongation by dividing the neurite outgrowth area into four segments. Of note, it is also worthwhile to visualize glial processes extending from the retinal explants via immunolabeling for glial fibrillary acidic protein (GFAP) (Gaublomme et al. 2013). As mentioned above, the expression of growth factors and guidance molecules by activated retinal glia highly contributes to RGC axonal lengthening (Muller et al. 2007; Lorber et al. 2009, 2012). In addition, glia might enhance RGC neurite outgrowth and pathfinding by acting as a scaffold for new neurites (Lorber et al. 2009; Toops et al. 2012).

\section{Ex vivo tissue explant studies in other vertebrates}

The use of retinal explants from rodents largely outnumbers those harvested from eyes of other amniotes, such as chicken and pig. Protocols for culturing retinal explants from chicken embryos have been described by different research groups (Hoff et al. 1999; Thangaraj et al. 2011; Paschon et al. 2013; Shirazi Fard et al. 2015), however, until now, chick explants have only rarely been employed to study axonal regeneration (Thanos et al. 1992). Likewise, porcine retinal explants are mostly used to analyze neuroprotection and cell survival, rather than neurite outgrowth (Wang et al. 2011; MartinezFernandez; de la Camara et al. 2014; Taylor et al. 2014; Bell et al. 2016). Regarding anamniote models, retinal explants harvested from goldfish or zebrafish have also been used to test the putative effect of both intrinsic and extrinsic factors on RGC outgrowth/regeneration, albeit to a more limited extend (Nusetti et al. 2005; Veldman et al. 2007, 2010; Cubillan et al. 2012; Ou et al. 2012; Ogai et al. 2014). To culture fish retinal explants, retinas are chopped into small squares and transferred to poly-L-lysine-coated well plates. After an incubation period of 1-4 days, the number of neurites, their length and/or density can be quantified (Becker and Becker 2002; Becker et al. 2004; Veldman et al. 2007, 2010; Elsaeidi et al. 2014; Ogai et al. 2014; Welte et al. 2015; Van Houcke et al. 2017).

In conclusion, methods for rodent ex vivo studies are well described. As the in vivo situation is better represented than in dissociated cell cultures, and (semi) high-throughput screening of compounds and/or experimental conditions is still possible, ex vivo approaches provide a valuable bridge between in vitro and in vivo studies. Although rodent research outnumbers explant studies in other vertebrates, insights from other animals may provide valuable insights as well. 


\section{In vivo models to study axonal regeneration}

\section{In vivo models in rodents and other amniotes}

\section{Models and methods to induce optic nerve regeneration}

Although ex vivo retinal explants closely resemble the natural situation, real in vivo models allow the study of axonal regeneration, guidance and reinnervation of the visual pathway in all its complexity. The retinofugal system, and more specifically RGCs and their axons, which constitute the optic nerve, has been used as an experimental model to study axonal regeneration in the mammalian CNS. To unravel the processes and mechanisms of axonal degeneration and to investigate the impact of a certain compound or intervention on long-distance axonal regeneration in vivo, two rodent injury models in the visual system have been used: optic nerve transection (ONT) followed by a PNG, and ONC combined with various growth-promoting treatments.

The ONT-PNG model was the first in which rodent RGC axonal regeneration was studied in vivo (So and Aguayo 1985) and provided the first convincing evidence of the capacity of mammalian RGCs to regrow and to make synaptic connections with their target neurons in the brain (VidalSanz et al. 1987), followed by recovery of visual function (Sauve et al. 1995; Thanos et al. 1997). In this model, the dural sheath of the optic nerve is longitudinally excised, after which the RGC axons are transected. Next, an autologous peripheral sciatic nerve graft is transplanted inside the dural sheath at the orbital stump of the transected optic nerve and directed to the superior colliculus. This enables some RGCs to regrow their injured axons over long distances through the PNG (Vidal-Sanz et al. 1987; Cen et al. 2012), reinnervate their target neurons, make synaptic connections, and restore visual function (Richardson et al. 1980, 1984; David and Aguayo 1981; Benfey and Aguayo 1982; Vidal-Sanz et al. 1991). This axonal regeneration through the graft is supposed to be mediated by molecules released by the graft and acting on RGCs soon after injury, and/or due to the absence of an inhibitory environment in the peripheral nerve (Bray et al. 1987). Importantly, whereas Schwann cells support axonal regeneration in the PNS, the contribution of oligodendrocytes to axonal growth and phagocytosis of debris is highly limited (Dezawa and Nagano 1993; Dezawa et al. 1997). However, the numbers of regenerated fibers remain quite low and the vast majority of RGCs just dies after axotomy (Watanabe et al. 1997). Of note, next to the retrobulbar transplantation described above, also intraretinal transplantation has been performed, in which the PNG was inserted into the retina via a scleral perforation, resulting in a more permissive environment for outgrowth since the axotomised
RGCs can access the PNG directly (So and Aguayo 1985; Berry et al. 1996, 1999; Inoue et al. 2000, 2002).

The ONC model, on the other hand, is currently the most widely used rodent injury model to study axonal regeneration in the rodent visual system. In this model, the optic nerve is damaged by crushing it, while the meningeal sheath remains intact. Importantly, surgical parameters, such as the duration of the crush or the distance of the crush site from the eye, can vary among research groups, which may contribute to differences in the timing and progress of the molecular and cellular processes following ONC. During the last decade, it has repeatedly been shown that RGCs can be induced to regrow axons over long distances after optic nerve injury (Sun et al. 2011; Pernet et al. 2013b; Belin et al. 2015; Bohm et al. 2015; Duan et al. 2015; Li et al. 2015; Sharma et al. 2015). Treatments that stimulate the acute inflammatory response after $\mathrm{ONC}$, such as lens injury or intravitreal injection of either the yeast cell-wall extract zymosan or the lipopeptide Pam3Cys, have proven to promote axon growth (Fischer and Leibinger 2012; Benowitz et al. 2017). Nowadays, most studies focus on the underlying mechanisms of inflammatory stimulation, and on reprogramming the intrinsic growth capacity in general. Among the various signaling pathways currently known to be involved in CNS axon regeneration, the mTOR pathway seems to be one of the most promising targets. Indeed, different research groups have shown that a remarkable regenerative response is induced upon deletion of PTEN, an upstream inhibitor of the mTOR pathway, whether or not combined with other growth-promoting treatments, such as inflammatory stimulation or SOCS3 deletion (Park et al. 2008; Kurimoto et al. 2010; Luo et al. 2013; Leibinger et al. 2016). Strikingly, it has recently been demonstrated that partial visual recovery after ONC can be achieved in rodents. One study that makes use of a combinatorial treatment of PTEN deletion, intraocular inflammatory stimulation and elevation of intracellular cyclic adenosine monophosphate (cAMP) levels, reports that mouse RGC axons can regrow along the entire visual pathway and reinnervate some of their target areas, coinciding with partial recovery of visual behavior (de Lima et al. 2012). Of note, this striking result has so far not been reproduced by other researchers using the same treatment paradigm (Luo et al. 2013). However, long-distance axon regeneration, target-specific reinnervation and partial recovery of visual behavior have been observed after the stimulation of mTOR activity via overexpression of the positive regulator Ras homolog enriched in brain 1 (Rheb1) in combination with visual stimulation or chemogenetic approaches to increase RGC activity (Geeraerts et al. 2016; Lim et al. 2016). The latter technique involves the use of synthetic Designer Receptors Exclusively Activated by Designer Drugs (DREADDs) to stimulate or suppress neuronal activity (Urban and Roth 2015; Lim et al. 2016). Despite these 
promising findings, full functional recovery has not yet been achieved in mammals, which can at least partly be attributed to aberrant growth trajectories of regenerating RGC axons. Indeed, misguidance of regenerating axons is one of the remaining problems and an important challenge in future research (Luo et al. 2013; Pernet et al. 2013a, b).

Of note, axonal regeneration and target reinnervation have also been studied in a mouse model of optic tract transection, where RGC axons are severed just proximal to the superior colliculus, minimizing the regenerative distance. There, it has been found that RGC axons can be stimulated to correctly reinnervate the superior colliculus by either a PTEN and SOCS3 co-deletion, or co-overexpression of osteopontin, insulin-like growth factor 1 (IGF-1), and CNTF. Although these treatments enable the formation of functional synapses, recovery of visual function requires additional stimulation of axon potentials conduction within the still unmyelinated axons, which can be achieved via the administration of voltage-gated potassium channel blockers (Bei et al. 2016).

Next to rodents, also other amniote vertebrates have been employed to study axonal regeneration within their visual system, albeit only sporadically. One early study describes for instance a model for optic nerve transection in both monkeys and rabbits (Quigley et al. 1995). ONC has also limitedly been applied in reptiles, where a heterogeneous, yet dysfunctional response to optic nerve injury is observed (Dunlop et al. 2004). However, after incomplete optic nerve injury, the presence of some axons that remained intact allows the regenerating ones to restore topography (Dunlop et al. 2007).

\section{Imaging modalities to evaluate optic nerve regeneration}

Traditional methods to visualize regenerating axons in the rodent visual system often rely on immunohistochemistry. This implies that at defined time points after injury, optic nerves are isolated, sectioned and stained, mostly for GAP43. This marker is expressed in growing axons of all vertebrates, both during development and regeneration (Doster et al. 1991; Leon et al. 2000; de Lima et al. 2012). However, while this approach is ideal for visualizing growing axons, its major drawback is the inability to label regenerated axons that stopped growing, and thus no longer express GAP43 (de Lima et al. 2012).

To circumvent this problem, axonal tracers can be used. In a first approach, anterograde tracers can be applied, either via intravitreal injection or at the nerve stump in case of ONT. They are taken up by RGCs and actively transported throughout the regenerating axons, which can thus be visualized after longitudinal sectioning of the optic nerve. The most commonly used tracers for anterograde transport are horse radish peroxidase (HRP), rhodamine isothiocyanate
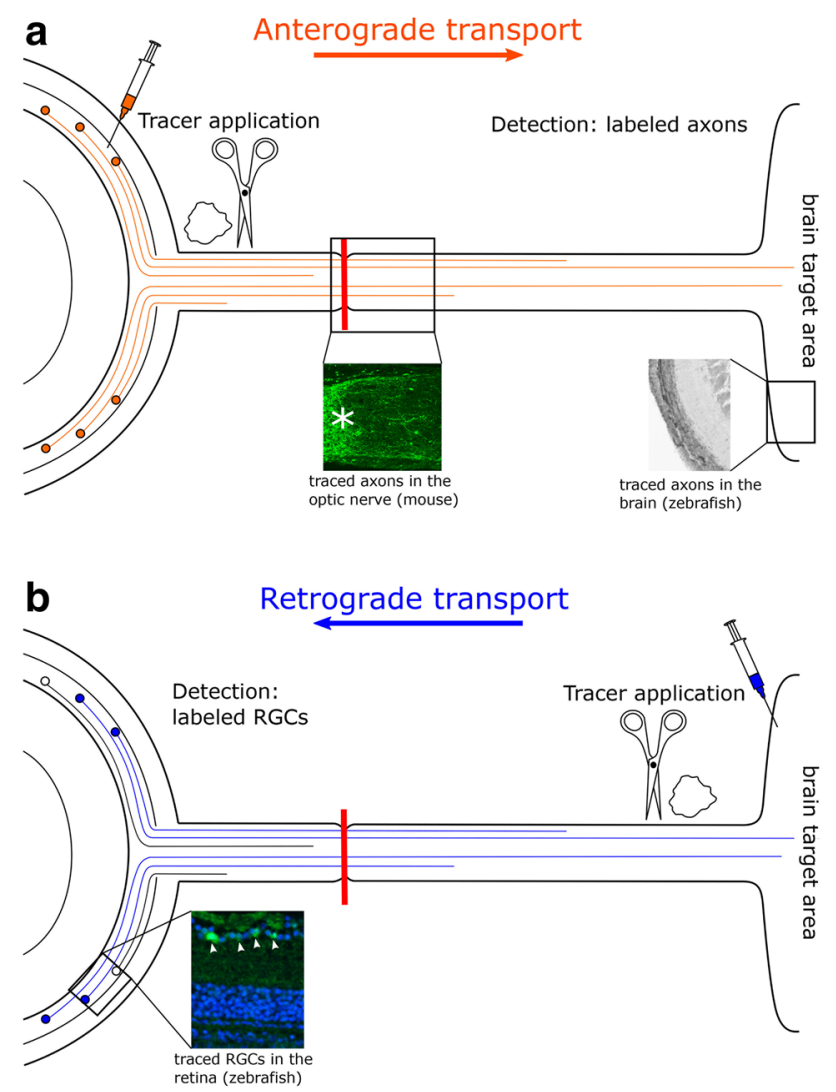

Fig. 3 Tracing methods to visualize regenerating RGC axons in vivo. Anterograde tracers are applied proximal to the injury site (indicated as a red line), either via intravitreal injection or impregnated in gelfoam, directly at the nerve stump. Labeled regenerated axons can be detected beyond the lesion site in the nerve or in the target area in the brain (a). For retrograde labeling, the tracer is administered at the distal nerve end (in gel-foam) or in the brain, and is transported back towards the retina, where the RGC somata that successfully regenerated their axons can be visualized and counted (b)

(RITC) and fluorescently labeled Cholera toxin subunit $b$ (CTB) (Thanos et al. 1987; Vidal-Sanz et al. 1987; Angelucci et al. 1996; Leon et al. 2000; Sapieha et al. 2003; Okada et al. 2005; de Lima et al. 2012) (Fig. 3a). In an alternative approach, the regenerating RGC population can also be retrogradely traced. This can be achieved either by positioning a tracer (such as HRP or Fluorogold) at the proximal end of the optic nerve stump, or by administering Fluorogold to the superior colliculus one week prior to axotomy. The retrograde tracers are transported back to the retina, where the RGCs that successfully regenerated their axons can be counted (Ng et al. 1995; Cui et al. 1999; Sapieha et al. 2003; Nadal-Nicolas et al. 2015a) (Fig. 3b). When comparing anterograde and retrograde tracing methods, it is clear that retrograde tracing has the advantage of straightforward quantification of regenerating RGCs (by simply counting their fluoro-labeled somata). On the other hand, anterograde tracing offers the possibility to quantify regenerating axons 
at multiple distances along the optic nerve or in the brain. Moreover, when combined with optical clearing (see below), anterograde but not retrograde tracing can be used to evaluate correct axonal navigation and pathfinding. However, it is important to note that the tracers may not only label regenerating, but also spared axons. Damaged (but not severed) axons possibly have a disrupted microtubule structure that restricts tracer transportation, which recovers later on. These spared axons will thus be invisible in early but not later phases of regeneration, and could thus be mistaken for regenerating axons (Fischer et al. 2017).

The use of transgenic mouse lines that express a fluorescent reporter gene would make immunostaining or tracing of regenerating RGC axons obsolete. Transgenic mice expressing cyan fluorescent protein (CFP) controlled by the Thy 1 promotor have been used in regenerative studies of the optic nerve. Here, the loss of CFP signal was correlated with the gradual decline of RGC axons after ONC or ischemic optic neuropathy (Dratviman-Storobinsky et al. 2008). Recently, a GAP43:luciferase-GFP mouse line was generated, which showed expression of GAP43 during neuronal development and after neuronal injury. Although generally silent in the adult CNS, expression is strongly upregulated in regenerating axons, thus omitting the need for tracer injections or post-mortem immunostainings (Gravel et al. 2011).

The methods described above require the samples to be sectioned and individually examined under a microscope, which is time consuming. Furthermore, sectioning results in axon fragmentation and loss of 3D information, making the identification of axon turns and branching laborious and difficult. To overcome these technical hurdles, optical clearing and whole mount imaging of the optic nerve are emerging methods of choice. Over the past decade, several experimental protocols have been developed to preserve and clear nervous tissues (Dodt et al. 2007; Chung and Deisseroth 2013; Ke et al. 2013; Pernet et al. 2013b; Luo et al. 2014). The combination of optically cleared tissue and multiphoton or light sheet fluorescence microscopy (LSFM) allows the visualization of regenerating axons in the entire optic nerve. To envisage the regenerating axons, an anterograde tracer is applied intraocularly, or alternatively, a transgenic reporter line can be used. Following cardiac perfusion and fixation, the tissue can be made optically clear using a variety of clearing solutions. A detailed overview of these agents and their properties has been described by Lee et al., 2016 (Lee et al. 2016). Several clearing methods have been applied to study optic nerve regeneration, such as benzyl alcohol-benzyl benzoate (BABB) (Luo et al. 2013; Pernet et al. 2013b; Yungher et al. 2015) and immunolabeling-enabled three-dimensional imaging of solvent-cleared organs (iDISCO) (Renier et al. 2014). The time required for a tissue to turn transparent varies between the different protocols. Once translucent, the specimen can be imaged using LSFM, thereby constructing a 3D image of the sample. In contrast to multiphoton microscopy, LSFM has a much larger working area as well as a faster imaging time, making this type of microscope ideal for this type of work (Erturk et al. 2012). One point of concern is that clearing agents can distort the morphology of the sample, either by shrinking or expanding the tissue during and after optical clearing. Nonetheless, quantitative measurements of regenerating axons can be made. Although this method has already changed the way we envisage and analyze regenerating axons, it has one major drawback in that it cannot be used for in vivo longitudinal experiments.

The possibility to visualize regenerating axons at consecutive time points within one animal can only be achieved by non-invasive imaging methods, such as manganeseenhanced magnetic resonance imaging (MEMRI). This technique makes use of the paramagnetic properties of manganese ions $\left(\mathrm{Mn}^{2+}\right)$, which are taken up by neurons via L-type voltage-gated $\mathrm{Ca}^{2+}$ channels (Narita et al. 1990), enabling the imaging of regenerating RGC axons (Ryu et al. 2002; Thuen et al. 2005, 2009; Chan et al. 2008; Haenold et al. 2012; Sandvig et al. 2012; Fischer et al. 2014; Sandvig and Sandvig 2014; Yang et al. 2016). To visualize optic nerve regeneration, $\mathrm{MnCl}_{2}$ is injected intravitreally, where it is taken up by the RGCs and anterogradely transported along axonal microtubule. As such, axonal de- and regeneration can be followed (Haenold et al. 2012). Recently, MEMRI has also been used to quantify structural changes in the retina and optic nerve following injury (Yang et al. 2016). However, an important drawback of MEMRI is the risk for toxicity when $\mathrm{Mn}^{2+}$ is administered repeatedly and/ or in high doses. Both in laboratory animals and in humans, serious adverse neurological effects of excessive manganese accumulation in the CNS have been reported (Brouillet et al. 1993; Aschner and Aschner 2005; Aschner et al. 2005; Erikson et al. 2005; Thuen et al. 2008). This drawback should be taken into account when applying MEMRI for the follow-up of optic nerve regeneration.

As an alternative to MEMRI, diffusion tensor magnetic resonance imaging (DTI) has also been applied to visualize axonal tracts without the need for contrast agents. This technique is based on the anisotropic diffusion of water molecules in axons, meaning that water tends to move along the axon, rather than perpendicular to it (Le Bihan et al. 2001; Beaulieu 2002). Thus, DTI can be used to noninvasively trace the optic nerve. However, this technique requires notoriously long scan times (up to several hours depending on the acquisition parameters). Therefore, the most widely spread DTI method is single-shot echo-planar imaging (EPI), a technique that allows data acquisition of a 2D image with a single excitation, making it faster and more efficient, and enabling in vivo scanning. However, the use of EPI is limited by low spatial resolutions and it may suffer from 
image distortions (Alexander et al. 2007; Sun et al. 2008; Bammer et al. 2009). Yet, thanks to technical advances in diffusion imaging over the last decade (which are beyond the scope of this review), brain studies on a larger scale have been made feasible. DTI has even been used in a recent study of the retinofugal pathway in human subjects (Kammen et al. 2016). Nevertheless, despite these advances of in vivo magnetic resonance imaging (MRI), the acquired resolution is lower than what can be obtained using conventional fluorescent microscopy, precluding the visualization of a single axon. It is also important to note that MRI requires specialized equipment and expertise.

Thus, although the technology to image regenerating axons is rapidly evolving, current methods are still limited in their capability to visualize single axons without harming the animal. Although the resolution of MRI images will further improve in the future, it is unclear whether they will ever reach the level required for single axon tracing. Nonetheless, the mammalian optical system remains an interesting model system to study axonal regeneration and will surely contribute to the development of more sensitive (and less harmful) imaging modalities.

\section{Zebrafish and other anamniotes}

\section{Models and methods to study spontaneous optic nerve regeneration}

Similar to mammals, many zebrafish studies focusing on axonal regeneration have been performed in the visual system. Surgical lesioning of the optic nerve is a routinely applied approach as well. It can be performed easily by gently lifting the eye out of its orbit and subsequently injuring the optic nerve. Two injury paradigms are currently in use: ONT and ONC. In the first model, the nerve is cut with scissors, thereby creating a proximal and distal nerve stump that are physically separated from each other. In contrast, in the ONC model, the nerve is crushed with forceps to separate the axons, but leaving the connective tissue around them intact, and thus holding the proximal and distal ends together (Becker et al. 2000; McCurley and Callard 2010; Fleisch et al. 2011; Lemmens et al. 2015; Van Houcke et al. 2017). As expected, the ONT model is somewhat more drastic and regeneration progresses slower as compared to ONC (Zou et al. 2013).

Immediately after optic nerve injury in adult zebrafish, the spontaneous regeneration program will be initiated. Interestingly, almost all RGCs will survive the lesion (Kato et al. 2013; Zou et al. 2013), which is highly contrasting to the extensive cell death observed in rodent models (Berkelaar et al. 1994; Kalesnykas et al. 2012; Nadal-Nicolas et al. 2015b; Yukita et al. 2015). The subsequent regenerative process can be divided in different major phases, based on a combination of morphological, physiological, biochemical and behavioral methods (McCurley and Callard 2010; Kato et al. 2013). After an initial injury response phase $(<1$ day post injury, dpi), the RGCs prepare for axonal outgrowth (1-7 dpi). This stage is characterized by a strong increase in the retinal expression of tubala ( $\alpha$-tubulin 1) and gap43, two well-known biochemical markers for the regeneration process. Subsequently, axons elongate and grow towards their target neurons in the brain (5-18 dpi). During this stage, tubala and gap43 are still upregulated, but their levels have started to decrease. To make functionally meaningful connections with their target neurons, RGC axons have to follow the correct path. Evidence suggests that there is indeed appropriate expression of guidance cues that can be used by the regenerating axons (Becker and Becker 2007), which is also reflected by the observation that only little reinnervation errors are made (Becker and Becker 2014). This is in contrast to the papers describing misguidance of induced axonal regeneration after ONC in rodents (Luo et al. 2013; Pernet et al. 2013a, b). RGC axons innervate different areas in the zebrafish brain, of which the optic tectum is the largest and by far the most studied target area in optic nerve regeneration research (Becker et al. 2000; Becker and Becker 2007; Erskine and Herrera 2007). The first regenerating axons reach the optic tectum within the first week after injury (Kato et al. 2013; Bhumika et al. 2015). Finally, after target contact and synaptic refinement (14-25 dpi), retinal expression of tubal and gap43 is decreased to baseline levels. Correct tectal reinnervation includes restoration of the retinotopic map, which is achieved around 6 weeks after the optic nerve lesion (Becker and Becker 2007, 2014). Complete visual repair, including complex behaviors with visual aspects such as chasing and shoaling, is restored at 60-100 dpi (Bormann et al. 1998; Hieber et al. 1998; Becker and Becker 2007, 2014; McCurley and Callard 2010; Kato et al. 2013).

The progression speed of the regenerative process is not only determined by the type of damage (ONC versus ONT), but is also highly affected by the precise position of the injury site along the ON. Damaging RGC axons close to the optic nerve head (i.e. close to the cell soma) results in more rapid regeneration, as compared to injuries closer to the optic chiasm (unpublished own observations). Therefore, it is essential to standardize and report the exact location of optic nerve injury.

Although the zebrafish is currently the most used anamniote model system for the study of optic nerve regeneration, goldfish have been extensively used as well, although predominantly in earlier years. It is, therefore, also a wellcharacterized model organism for the study of axonal regeneration in the visual system (Nona 1995; Matsukawa et al. 2004). Similar to zebrafish, the regenerative process after optic nerve injury can be divided in different phases, 
and functional recovery is complete after approximately 6 months, which is thus much slower than in zebrafish (Meyer and Kageyama 1999; Rasmussen and Sagasti 2016). Another important disadvantage of the goldfish model is the lack of genetic tools (Rasmussen and Sagasti 2016), which contributes to the decreased popularity of the goldfish in recent years.

Apart from fish models, amphibian species (such as Rana pipiens, Hyla Moorei and Xenopus laevis) hold great potential for in vivo regeneration studies. Intriguingly, in adult amphibia, optic nerve axotomy induces cell death in approximately $40-70 \%$ of the RGCs, yet, the surviving RGCs partially or even fully regenerate and connect with their targets in the optic tectum (Humphrey and Beazley 1985; Beazley et al. 1986; Soto et al. 2003; Duprey-Diaz et al. 2016). The time course and spatial distribution of regenerating axons after optic nerve injury is well-characterized. Tectal reinnervation of frog RGCs starts from about 6 weeks after axotomy and RGC axons restore a topographic visual projection into the optic tectum, which coincides in most species with recovery of normal visual responses (Maturana et al. 1959; Singman and Scalia 1991; Dunlop et al. 1997; Dunlop 2003; Liu et al. 2012).

\section{Imaging modalities to evaluate optic nerve regeneration}

To study correct pathfinding and tectal reinnervation after optic nerve injury in zebrafish, a number of different in vivo tracing approaches are in use (Becker et al. 2000; Becker and Becker 2002).

First, anterograde labeling techniques can be performed (Fig. 3a). In this approach, the tracer molecules are delivered proximal to the injury site, either via injections in the eye (Kaneda et al. 2008; Elsaeidi et al. 2014) or by transecting the optic nerve and applying it there directly (Becker et al. 2000, 2004). The tracer will be taken up by regrowing axons, and transported towards the growth cones. Detection is done beyond the injury site, usually the axons that have reached the optic tectum are quantified on transverse brain sections. As in rodent models, anterograde labeling has the advantage that the path of the regenerating axons can be followed, allowing the detection of possible navigation errors or incorrect patterning. Of note, in case the tracer is applied directly on the nerve, for which additional severing (e.g. transection of the optic nerve) is necessary, it is of importance that the tracers are applied and transported quickly, before the rapid disintegration of the distal part of damaged optic nerve fibers (Becker et al. 2000). Frequently used anterograde tracers are tagged dextrans (Elsaeidi et al. 2014) and biocytin. The latter is transported very rapidly, and labeling axons in the adult zebrafish optic tectum takes only about 2.5-4 h. Making use of biocytin's high affinity for avidin, traced axons in the tectum can be easily visualized with common immunohistochemistry techniques (Becker et al. 2000, 2004; Munzel et al. 2014; Bhumika et al. 2015; Lemmens et al. 2015, 2016).

On the other hand, retrograde labeling methods are better suited to analyze regeneration over shorter distances and/or during the early stages of the regenerative process (Fig. 3b). Hereby, a few days post lesioning, the optic nerve is transected about 1-3 mm distal to the original injury site to place the tracer molecule, which is then transported towards the retina by the regenerated axons. The latter approach offers the advantage of easily counting labeled RGC somata in the retina. Furthermore, it allows calculating the percentage of RGCs that contributes to regeneration (Van Houcke et al. 2017). For retrograde labeling in zebrafish, mostly dextrans coupled to fluorophores are in use (Zou et al. 2013; Elsaeidi et al. 2014; Welte et al. 2015; Williams et al. 2015; Van Houcke et al. 2017). In addition, Zou and coworkers have developed a retrograde tracing method without the need for additional severing of the optic nerve (Zou et al. 2014). After removing the skull at the side where regenerating RGC axons are reinnervating the optic tectum, a piece of gelfoam impregnated with the lipophilic dye $1,1^{\prime}$-dioctadecyl$3,3,3^{\prime}, 3^{\prime}$-tetramethylindocarbocyanine perchlorate (DiI) is placed on the tectum. The tracer DiI is highly fluorescent and photostable when incorporated into the membrane, and the signal is preserved for a long time (Choi et al. 2002). DiI is taken up by RGC axons and transported towards the retina where the labeled RGC somata can be counted (Zou et al. 2014). For regeneration studies, DiI is typically applied a few days after the injury, thereby only targeting RGC axons that have already regrown into the optic tectum. Of note, one should take into consideration that some RGC axons might have reached the tectum, but have not yet transported the dye back to their somata at the time of cell counting, yielding an underestimation of regenerated RGCs (Zou et al. 2013).

Endogenous markers that are specifically expressed in regenerating RGCs and present in their axons permit bypassing the need to trace the regrowing axons, a clear advantage over both methods described above. However, this approach still requires immunohistochemical staining for the endogenous marker. Two well-characterized genes, tubala and gap 43, meet the criteria of such a marker. Indeed, both tubala and gap43 have long been recognized as a hallmark for axonal growth during CNS development in vertebrates, while their expression declines drastically upon CNS maturation. However, in neurons with regenerative potential, such as zebrafish RGCs after optic nerve injury, they are re-induced throughout the regeneration process, which could thus be followed by keeping track of gap 43 or tubala expression, as was discussed in section "Imaging modalities to evaluate optic nerve regeneration" (Hieber et al. 1998; Goldman et al. 2001; Kaneda et al. 2008; Udvadia 2008; 
Kusik et al. 2010; McCurley and Callard 2010; Diekmann et al. 2015b).

In this prospect, transgenic zebrafish lines where GFP expression is driven from either a fragment of the zebrafish alpha1 tubulin gene (Tg(tubala:GFP)) (Goldman et al. 2001), or the compact Takifugu rubripes gap43 promoter (Tg(fgap43:GFP)) (Udvadia 2008) were created. In both cases, GFP expression very closely resembles the endogenous expression of tubala or gap43, respectively. Thus, these two comparable transgenic lines form useful tools to study the underlying mechanisms of the flawless axon regeneration in zebrafish in vivo (Veldman et al. 2010; Elsaeidi et al. 2014; Diekmann et al. 2015a, b; Williams et al. 2015). In a recently described method, the $T g($ fgap $43: G F P)$ line was employed to study the (re)growth of individual axons within whole mount optic nerves, which were cleared in a way similar to what has been described above in rodents (Diekmann et al. 2015a, b). This approach, which enables detailed visualization of the regenerating RGC axons without the need for tissue sectioning, might open up new avenues to study axonal regeneration in zebrafish.

\section{Evaluation of functional recovery after optic nerve injury}

Complete recovery after optic nerve injury does not only require long-distance axon regeneration and subsequent reinnervation of the appropriate brain regions, but also implies full restoration of visual function. In the following sections, electrophysiological techniques, as well as the most important behavioral assays that are currently in use, are discussed.

\section{Electrophysiology}

Historically, electrophysiology has been an important technique to investigate optic nerve regeneration and target reinnervation. It allows rapid and precise assessment of the patterning of RGC axons in the visual brain areas (Stirling et al. 1998). Not surprisingly, these studies are mostly performed in species that show at least some spontaneous regeneration. In Xenopus, electrical activity after a stimulus light spot is recorded by an electrode that is positioned at different sites on the tectum (Gaze et al. 1963). Electrophysiology has been used to study retinotectal mapping (Keating and Gaze 1970; Gaze et al. 1974; Willshaw et al. 1983) and tectal reinnervation of regenerating Xenopus RGC axons. Their presence in the tectum can be demonstrated electrophysiologically around 10-20 days after optic nerve injury (Gaze and Grant 1978). Similar measurements of electrical activity in the regenerating retinotectal system have also been performed in goldfish and zebrafish (Northmore 1989a, b; McDowell et al. 2004).
In contrast to fish and frogs, optic nerve regeneration in lizards is incomplete. Anatomical studies revealed that RGC axons arrive in their target areas around 2 months after the injury but lack topographic order. Yet, there is electrophysiological evidence for a transient ordering. By recording the electrical activity at different locations on the tectal surface, a limited topographic order could be observed between 4.5 and 6 months after optic nerve damage, which seems to disappear again thereafter (Stirling et al. 1999). Notably, visual training seems to improve functional recovery, likely by stabilizing and refining the transient retinotectal map, both at morphological and electrophysiological levels (Beazley et al. 2003).

Electrophysiological measurements have also been employed to study functional recovery after optic nerve injury in rodents. However, because of the restricted regenerative capacity, the technique can only be used in injury models where the damage to the optic nerve is only partial, or where regeneration is stimulated. Functional recovery can be assessed by stimulating the animal with a flash of light, and measuring the visually evoked potential (VEP) in the visual cortex (Yoles et al. 1996; Miyake et al. 2007). Alternatively, an ex vivo preparation of the optic nerve can be used for electrophysiological measurements. After stimulation at the proximal end of the nerve, action potentials are recorded at the distal end (Duvdevani et al. 1990; Sautter et al. 1991; Yoles et al. 1996). Additionally, in a model where RGC axons are provided with a PNG, electrical activity of the regenerating nerves can be measured through an electrode carrier device that has been implanted at the optic nerve stump. Regenerating axons grow through perforations in the electrode carrier, which is then used for in vivo electrophysiological measurements of the optic nerve (Heiduschka et al. 2001).

In conclusion, electrophysiology encompasses a range of valuable approaches that can be used to assess functional recovery after optic nerve injury. However, this technique has not been used in more recent publications, as the field seems to have adopted other methods to evaluate restoration of visual function, such as the behavioral assays described below.

\section{Behavioral assays}

\section{Vision-driven behavioral tests in rodents}

Although functional recovery after optic nerve regeneration in mammals remains challenging, some recent studies have reported partial reinnervation of visual target areas in the brain, as well as limited functional recovery, as demonstrated using behavioral assays. The list of behavioral tests below is not intended to be exhaustive, but provides an overview of the assays that have already been described in the 
Fig. 4 Schematic representation of visual behavior assays in adult rodents. The behavioral tests represented here are the optomotor response (OMR), the looming response test, the pupillary light reflex (PLR), and the visual cliff test. For the OMR, the large arrow indicates the rotation direction of gratings, while the small arrow indicates according head movements
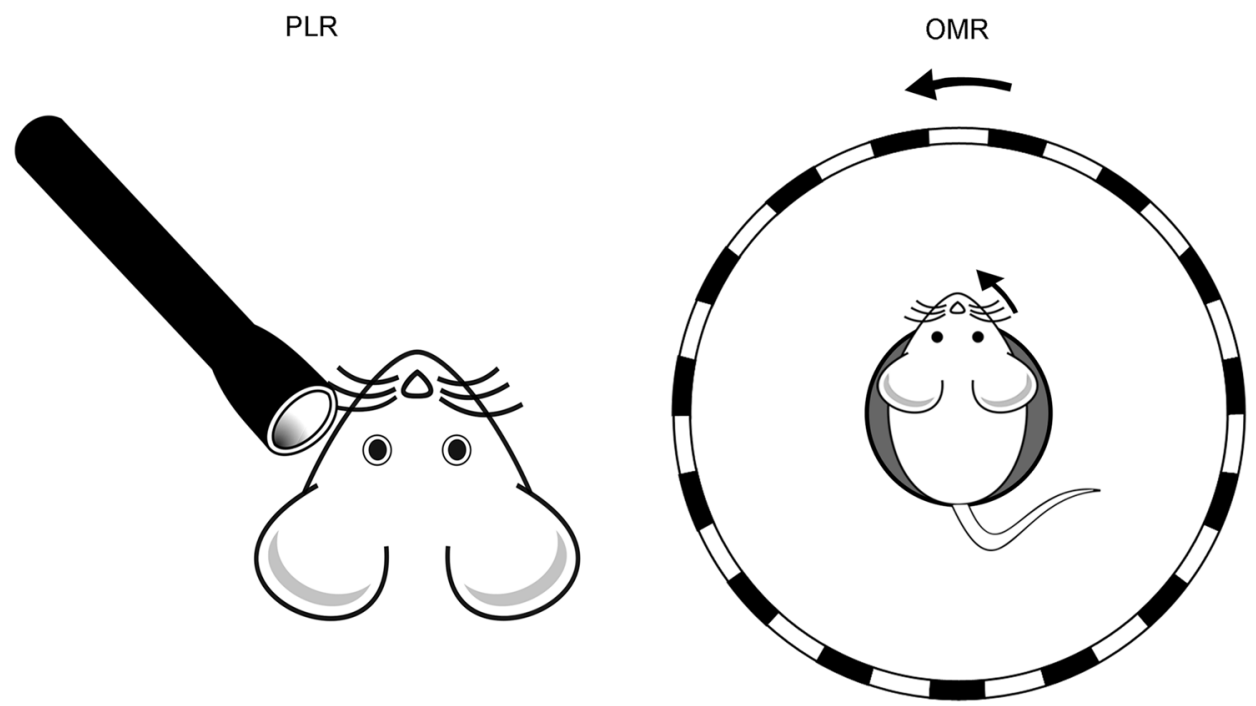

looming response test

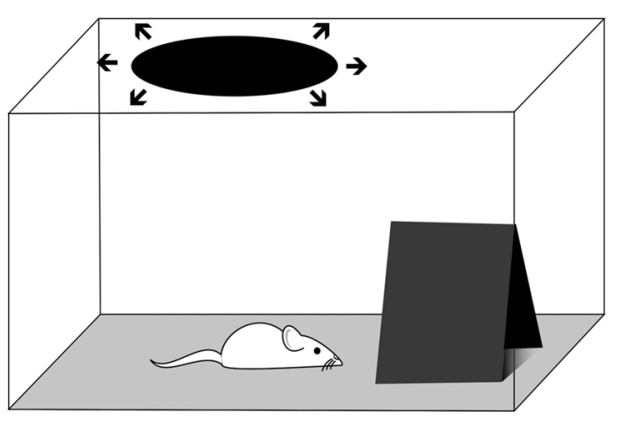

visual cliff test

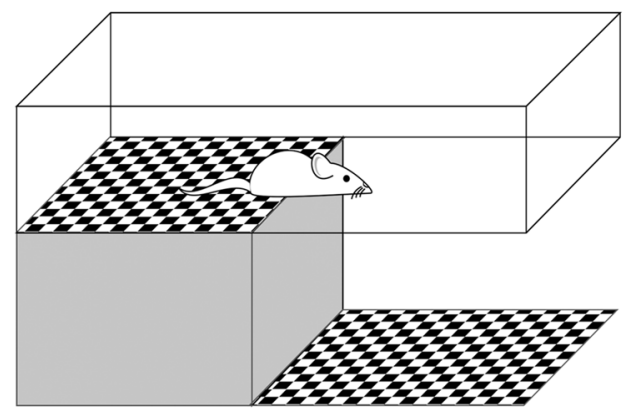

context of optic nerve regeneration (de Lima et al. 2012; Lim et al. 2016) (Fig. 4).

A first vision-guided behavioral test for rodents is based on the pupillary light reflex (PLR). Here, visual function is evaluated by measuring the constriction of the pupil upon shining light into the eye of dark-adapted animals. The response depends only on proper connections between intrinsically photosensitive RGCs and the olivary pretectal nucleus (Chen et al. 2011). After optic nerve injury and subsequent pro-regenerative treatment, one study found a (partial) recovery of the PLR response (de Lima et al. 2012), while another did not (Lim et al. 2016). Of note, the results may be compromised by melanopsin signalling within the iris, which can cause pupillary constriction without neural input (Xue et al. 2011).

The PLR can be complemented with the optomotor response (OMR), which relies on the accessory optic system (Sun et al. 2015). It is elicited by a moving repetitive stimulus pattern, typically vertical black and white stripes. Hereto, an unrestrained mouse or rat is positioned on a small platform surrounded by computer monitors facing inward. If the animal does perceive the rotating striped pattern that is shown on the screens, it will move its head in the direction of the drifting gratings. To assess visual function, the lowest spatial frequency and/or contrast that can still be tracked, is measured (Prusky et al. 2004; Jeffrey et al. 2011). Significant, but not yet complete recovery of the OMR has been achieved after optic nerve injury followed by growth-stimulating treatments (de Lima et al. 2012; Lim et al. 2016). Of note, restoration of the OMR has also been shown in the optic tract transection model, after regenerative treatment that included PTEN deletion (Bei et al. 2016). This behavioral assay could thus serve as an alternative model to study functional recovery.

Third, the looming avoidance test assesses the response to a visual fear cue, which is presented as a dark expanding disk overhead, to which mice react by either freezing or fleeing to an escape area. This behavior is dependent on the retino-collicular pathway. In the experimental setup, a chamber where the animal can hide is provided, and the looming stimulus is presented at the top of the chamber. Visual function is evaluated by scoring the behavioral response to the stimulus (Yilmaz and Meister 2013; Zhao et al. 2014; Shang et al. 2015), and can be partially restored after optic 
nerve injury followed by a growth-stimulating treatment (Lim et al. 2016).

Another well-described assay is the visual cliff test. Here, depth avoidance behavior is tested in a chamber with a transparent floor, half of which is resting on a platform ('safe side'), while the other half is hanging elevated from the ground ('cliff side'). To emphasize the illusion of a dropoff, a checkerboard pattern is placed under both sides of the chamber (Glynn et al. 2003). An animal is scored for the percentage of time it spends at the safe side, or for the choice it makes on which side to step down when put at the border between the two regions (Pinto and Enroth-Cugell 2000). As depth perception requires proper connections to the dorsal lateral geniculate nucleus (dLGN) and the primary visual cortex (V1), cliff avoidance is considered more complex than the behaviors described above, and significant recovery of it after optic nerve injury has not yet been achieved (de Lima et al. 2012; Lim et al. 2016).

Finally, visual function can also be assessed via the circadian activity patterns. Mice are mostly active during nighttime, and are capable of adapting this rhythm to phase shifts in the light/dark cycle. This synchronization depends on proper connections between intrinsically photosensitive RGCs (ipRGCs) and the suprachiasmatic nucleus (SCN) (Chen et al. 2011). By monitoring the activity of individual mice that received a pro-regenerative treatment after optic nerve injury, it has been shown that their activity pattern is again synchronized with the light/dark cycle, although a considerable delay compared to healthy mice is observed (de Lima et al. 2012).

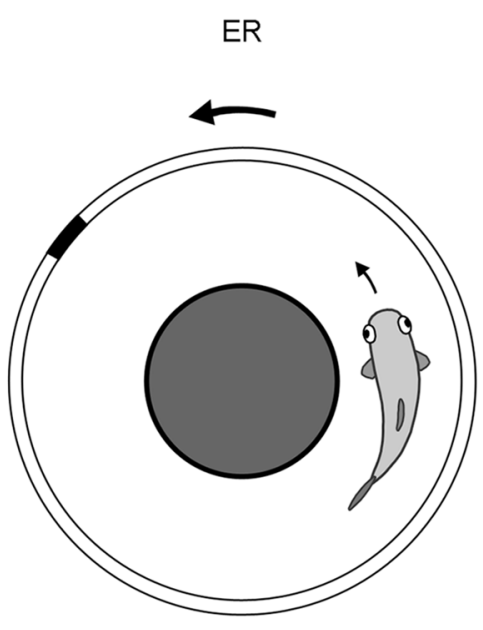

$\operatorname{DLR}(a)$
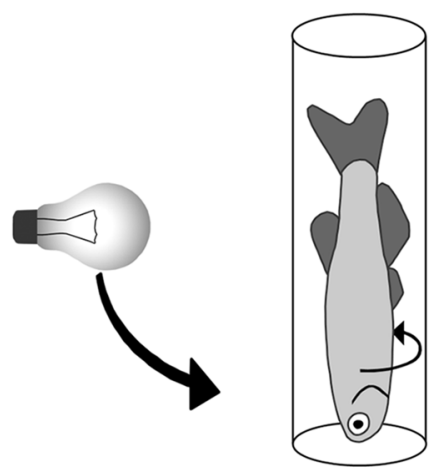

Fig. 5 Schematic representation of visual behavior assays in adult zebrafish. The behavioral tests represented here are the escape response (ER), the optomotor response (OMR), the optokinetic response (OKR), and the dorsal light response (DLR). For the latter, two different setups are shown, which are marked with $\mathbf{a}$ and $\mathbf{b}$. Large arrows indicate the rotation direction of gratings (ER, OMR, OKR) or the light source (DLR), small arrows illustrate movement of the fish (ER, OMR, DLR), or its eyes (OKR) 
Table 1 Recovery time of different visual responses after optic nerve injury

\begin{tabular}{lll}
\hline Visual behaviour & Recovery time & References \\
\hline Escape response & 29 days & Elsaeidi et al. (2014) \\
Optomotor response & $28-25$ days & Kato et al. (2013) \\
& & $\begin{array}{l}\text { Zou et al. (2013) } \\
\text { Becker and Becker (2014) }\end{array}$ \\
Optokinetic response & 14 days & Kato et al. (2013) \\
& & Becker and Becker (2014) \\
Dorsal light response & 18 days & Diekmann et al. (2015b) \\
\hline
\end{tabular}

Given values are approximate

\section{Vision-driven behavioral tests in zebrafish}

In high contrast to rodents, zebrafish spontaneously recover from optic nerve injuries, also at the functional level. A non-exhaustive list of behavioral tests to investigate the re-establishment of visually-guided behavior in fish is provided below (Fig. 5; Table 1) (Kaneda et al. 2008; Zou et al. 2013; Elsaeidi et al. 2014; Ogai et al. 2014; Diekmann et al. 2015a).

A first simple behavioral assay is the so-called 'escape response' (ER). This visual test is based on the tendency of fish to hide for threatening objects, or a 'phantom predator'. Hereto, fish are placed in a transparent round aquarium, with an opaque column in its center. A rotating drum containing a black segment in a white background positioned around the aquarium will elicit an escape response, as it triggers the fish to hide behind the central pole ( $\mathrm{Li} 2001$; Neuhauss 2003). Although the ER is a robust response, a major drawback of this assay is the fact that it takes large defects in visual function to be effectively picked up, making it difficult to ascribe it to an exact visual function (Cameron et al. 2013).

Related to the ER is the OMR, the same behavior that is frequently tested in rodents. In the fish setup of this test, the animal is allowed to swim freely in a round aquarium with an opaque center. If it does perceive the rotating pattern, it tends to follow the direction of movement (Maaswinkel and Li 2003; Neuhauss 2003), thereby circling around the midpoint. However, since zebrafish continue to swim randomly if no pattern is perceived, care should be taken when analyzing the obtained data. After optic nerve injury, the OMR starts to recover around 2 weeks, and is fully restored at $28-35 \mathrm{dpi}$, which is in accordance with the time course of tectal reinnervation, as previously mentioned (Kaneda et al. 2008; Kato et al. 2013; Zou et al. 2013; Becker and Becker 2014).

Another well described and frequently used behavioral test is based on the optokinetic response (OKR), which consists of stereotyped eye movements that are innate to virtually all vertebrates, evoked by movements in the environment around the subject. First, eyes will move slowly and smoothly in accordance with the direction of movement, which is followed by a fast reset of eye position in the opposite direction, also called saccades (Huang and Neuhauss 2008; Mueller and Neuhauss 2010; Tappeiner et al. 2012). For OKR measurements, the same black-andwhite striped revolving drum as for the OMR can be used, however, restraining the fish body is essential to record eye movements only. In general, the OKR is more relevant and reliable than the OMR and the ER, it is more robust and can be quantified more easily (Mueller and Neuhauss 2010; Cameron et al. 2013). Importantly, the OKR recovers more quickly than the OMR. A complete OKR is already achieved 14 days after optic nerve axotomy. The discrepancy between recovery time for OKR and OMR, might be explained by the fact that different neuronal circuits are needed for both responses (Kato et al. 2013).

Finally, a straightforward visual test based on the dorsal light response (DLR) has been applied to assess optic nerve regeneration in adult zebrafish. The DLR is the tendency of fish to turn their back to the light source, as light will always come from above in their natural environment. Different set-ups to assess the DLR can be employed. One possibility is to place the fish in a tight tube, and to spin a light source slowly around it. If the visual system is intact, the fish will turn its back towards the direction of the light (Yanagihara et al. 1993; Neuhauss 2003). In the context of visual impairment after optic nerve damage, the DLR can also be easily observed as a slightly oblique swimming position. Indeed, fish will swim with the undamaged eye downwards, thereby attempting to equalize the amount of light entering both eyes. This tilted position will gradually return to the normal horizontal posture upon the regeneration process. Thus, measuring the angle between the horizon and the imaginary line connecting the center of both eyes in a frontal view is a simple method to evaluate functional recovery after optic nerve damage, which does not require specialized software or hardware equipment (Callahan and Mensinger 2007; Lindsey and Powers 2007; Diekmann et al. 2015a). Under normal conditions, the swimming position is already significantly improved within 2 weeks after ONC (Diekmann et al. 2015a).

In conclusion, the extended availability of different behavioral tests in rodents and zebrafish will contribute to a better understanding of the functional repair of visual functions, as they functionally complement the data from morphological studies. Insights gained from behavioral tests might be of great interest to further explore the regenerative potential of certain molecules and pathways after optic nerve injury and in related neurodegenerative diseases. 


\section{Conclusion}

Dysfunction of the CNS after brain injury or in neurodegenerative diseases has a significant effect on human life quality. As adult mammals lack a robust regenerative capacity, neurodegeneration in the mammalian CNS is irreversible. Much of the progress related to studying axonal regeneration comes from investigations using the retinofugal system in rodents and zebrafish. Complementary in vitro, ex vivo and in vivo approaches in the visual system enable profound investigations to elucidate the underlying mechanisms of axonal de- and regeneration. In addition, these models are amenable to test novel drug compounds or therapeutic strategies to overcome regenerative failure in the mammalian CNS. The development of higher-resolution imaging technologies, aiming to better visualize or trace regenerating axons in rodents and zebrafish, is boosting, as is the generation of novel transgenic animal lines, further simplifying and speeding up future studies on axonal regeneration. Notably, these novel tools should also allow a better investigation on axonal guidance mechanisms and growth cone dynamics, which is currently, next to long-distance regeneration, a major hurdle for proper target innervation. Finally, the continued development of fast and clear assays to evaluate functional visual recovery after optic nerve injury in different model organisms will contribute to a better understanding of the multifactorial causes underlying the limited regenerative capacity in the mammalian CNS and to our search for novel integrative treatment strategies.

Acknowledgements The authors are financially supported by national Hercules Grants (AKUL/09/038 and AKUL1309) and Grants from the Research Council of KU Leuven (KU Leuven BOF-OT/10/033), the Research Foundation Flanders (Belgium, FWO G.0054.12, G0B2315N and fellowships to IB and LDG), and Flanders Innovation and Entrepreneurship (Belgium, IWT, fellowships to EG, TB and IVH).

\section{Compliance with ethical standards}

Conflict of interest The authors declare that they have no conflict of interest.

Research involving human patients This article does not contain any studies with human participants performed by any of the authors.

Research involving animals All applicable international, national, and/ or institutional guidelines for the care and use of animals were followed. All procedures performed in studies involving animals were in accordance with the ethical standards of the institution or practice at which the studies were conducted.

Open Access This article is distributed under the terms of the Creative Commons Attribution 4.0 International License (http://creativecommons.org/licenses/by/4.0/), which permits unrestricted use, distribution, and reproduction in any medium, provided you give appropriate credit to the original author(s) and the source, provide a link to the Creative Commons license, and indicate if changes were made.

\section{References}

Ahmed Z, Berry M, Logan A (2009) ROCK inhibition promotes adult retinal ganglion cell neurite outgrowth only in the presence of growth promoting factors. Mol Cell Neurosci 42:128-133

Ahmed Z, Aslam M, Lorber B, Suggate EL, Berry M, Logan A (2010) Optic nerve and vitreal inflammation are both RGC neuroprotective but only the latter is RGC axogenic. Neurobiol Dis $37: 441-454$

Alexander AL, Lee JE, Lazar M, Field AS (2007) Diffusion tensor imaging of the brain. Neurotherapeutics 4:316-329

Angelucci A, Clasca F, Sur M (1996) Anterograde axonal tracing with the subunit B of cholera toxin: a highly sensitive immunohistochemical protocol for revealing fine axonal morphology in adult and neonatal brains. J Neurosci Methods 65:101-112

Ard MD, Bunge MB, Wood PM, Schachner M, Bunge RP (1991) Retinal neurite growth on astrocytes is not modified by extracellular matrix, anti-L1 antibody, or oligodendrocytes. Glia 4:70-82

Aschner JL, Aschner M (2005) Nutritional aspects of manganese homeostasis. Mol Aspects Med 26:353-362

Aschner M, Erikson KM, Dorman DC (2005) Manganese dosimetry: species differences and implications for neurotoxicity. Crit Rev Toxicol 35:1-32

Atkinson J, Panni MK, Lund RD (1999) Effects of neurotrophins on embryonic retinal outgrowth. Brain Res Dev Brain Res 112:173-180

Attardi DG, Sperry RW (1963) Preferential selection of central pathways by regenerating optic fibers. Exp Neurol 7:46-64

Bammer R, Holdsworth SJ, Veldhuis WB, Skare ST (2009) New methods in diffusion-weighted and diffusion tensor imaging. Magn Reson Imaging Clin N Am 17:175-204

Bates CA, Meyer RL (1997) The neurite-promoting effect of laminin is mediated by different mechanisms in embryonic and adult regenerating mouse optic axons in vitro. Dev Biol 181:91-101

Beaulieu C (2002) The basis of anisotropic water diffusion in the nervous system - a technical review. NMR Biomed 15:435-455

Beazley LD, Darby JE, Perry VH (1986) Cell death in the retinal ganglion cell layer during optic nerve regeneration for the frog Rana pipiens. Vis Res 26:543-556

Beazley LD, Rodger J, Chen P, Tee LB, Stirling RV, Taylor AL, Dunlop SA (2003) Training on a visual task improves the outcome of optic nerve regeneration. J Neurotrauma 20:1263-1270

Becker CG, Becker T (2002) Repellent guidance of regenerating optic axons by chondroitin sulfate glycosaminoglycans in zebrafish. J Neurosci 22:842-853

Becker CG, Becker T (2007) Growth and pathfinding of regenerating axons in the optic projection of adult fish. J Neurosci Res 85:2793-2799

Becker T, Becker CG (2014) Axonal regeneration in zebrafish. Curr Opin Neurobiol 27:186-191

Becker CG, Meyer RL, Becker T (2000) Gradients of ephrin-A2 and ephrin-A5b mRNA during retinotopic regeneration of the optic projection in adult zebrafish. J Comp Neurol 427:469-483

Becker CG, Schweitzer J, Feldner J, Schachner M, Becker T (2004) Tenascin- $\mathrm{R}$ as a repellent guidance molecule for newly growing and regenerating optic axons in adult zebrafish. Mol Cell Neurosci 26:376-389

Bei F, Lee HH, Liu X, Gunner G, Jin H, Ma L, Wang C, Hou L, Hensch TK, Frank E, Sanes JR, Chen C, Fagiolini M, He Z (2016) Restoration of visual function by enhancing conduction in regenerated axons. Cell 164:219-232

Belin S, Nawabi H, Wang C, Tang S, Latremoliere A, Warren P, Schorle H, Uncu C, Woolf CJ, He Z, Steen JA (2015) Injuryinduced decline of intrinsic regenerative ability revealed by quantitative proteomics. Neuron 86:1000-1014 
Bell K, Wilding C, Funke S, Perumal N, Beck S, Wolters D, HolzMuller J, Pfeiffer N, Grus FH (2016) Neuroprotective effects of antibodies on retinal ganglion cells in an adolescent retina organ culture. J Neurochem 139:256-269

Benfey M, Aguayo AJ (1982) Extensive elongation of axons from rat brain into peripheral nerve grafts. Nature 296:150-152

Benowitz LI, Popovich PG (2011) Inflammation and axon regeneration. Curr Opin Neurol 24:577-583

Benowitz LI, Yin Y (2007) Combinatorial treatments for promoting axon regeneration in the CNS: strategies for overcoming inhibitory signals and activating neurons' intrinsic growth state. Dev Neurobiol 67:1148-1165

Benowitz LI, He Z, Goldberg JL (2017) Reaching the brain: advances in optic nerve regeneration. Exp Neurol 287:365-373

Berkelaar M, Clarke DB, Wang YC, Bray GM, Aguayo AJ (1994) Axotomy results in delayed death and apoptosis of retinal ganglion cells in adult rats. J Neurosci 14:4368-4374

Bermel C, Tonges L, Planchamp V, Gillardon F, Weishaupt JH, Dietz GP, Bahr M, Lingor P (2009) Combined inhibition of Cdk5 and ROCK additively increase cell survival, but not the regenerative response in regenerating retinal ganglion cells. Mol Cell Neurosci 42:427-437

Berry M, Carlile J, Hunter A (1996) Peripheral nerve explants grafted into the vitreous body of the eye promote the regeneration of retinal ganglion cell axons severed in the optic nerve. J Neurocytol 25:147-170

Berry M, Carlile J, Hunter A, Tsang W, Rosustrel P, Sievers J (1999) Optic nerve regeneration after intravitreal peripheral nerve implants: trajectories of axons regrowing through the optic chiasm into the optic tracts. J Neurocytol 28:721-741

Berry M, Ahmed Z, Lorber B, Douglas M, Logan A (2008) Regeneration of axons in the visual system. Restor Neurol Neurosci 26:147-174

Bhumika S, Lemmens K, Vancamp P, Moons L, Darras VM (2015) Decreased thyroid hormone signaling accelerates the reinnervation of the optic tectum following optic nerve crush in adult zebrafish. Mol Cell Neurosci 68:92-102

Bocker-Meffert S, Rosenstiel P, Rohl C, Warneke N, Held-Feindt J, Sievers J, Lucius R (2002) Erythropoietin and VEGF promote neural outgrowth from retinal explants in postnatal rats. Investig Ophthalmol Vis Sci 43:2021-2026

Bohm MR, Prokosch V, Bruckner M, Pfrommer S, Melkonyan H, Thanos S (2015) BetaB2-crystallin promotes axonal regeneration in the injured optic nerve in adult rats. Cell Transplant 24:1829-1844

Bormann P, Zumsteg VM, Roth LW, Reinhard E (1998) Target contact regulates GAP-43 and alpha-tubulin mRNA levels in regenerating retinal ganglion cells. J Neurosci Res 52:405-419

Bray GM, Villegas-Perez MP, Vidal-Sanz M, Aguayo AJ (1987) The use of peripheral nerve grafts to enhance neuronal survival, promote growth and permit terminal reconnections in the central nervous system of adult rats. J Exp Biol 132:5-19

Brocco MA, Panzetta P (1997) Survival and differentiation of purified embryonic chick retinal ganglion cells cultured at low density in a chemically defined medium. J Neurosci Methods 75:15-20

Brocco MA, Panzetta P (1999) Survival and process regrowth of purified chick retinal ganglion cells cultured in a growth factor lacking medium at low density. Modulation by extracellular matrix proteins. Brain Res Dev Brain Res 118:23-32

Brouillet EP, Shinobu L, McGarvey U, Hochberg F, Beal MF (1993) Manganese injection into the rat striatum produces excitotoxic lesions by impairing energy metabolism. Exp Neurol 120:89-94

Buyens T, Gaublomme D, Van Hove I, De Groef L, Moons L (2014) Quantitative assessment of neurite outgrowth in mouse retinal explants. Methods Mol Biol 1162:57-71
Callahan MP, Mensinger AF (2007) Restoration of visual function following optic nerve regeneration in bluegill (Lepomis macrochirus) $\times$ pumpkinseed (Lepomis gibbosus) hybrid sunfish. Vis Neurosci 24:309-317

Cameron DJ, Rassamdana F, Tam P, Dang K, Yanez C, Ghaemmaghami S, Dehkordi MI (2013) The optokinetic response as a quantitative measure of visual acuity in zebrafish. J Vis Exp

Cen LP, Luo JM, Geng Y, Zhang M, Pang CP, Cui Q (2012) Long-term survival and axonal regeneration of retinal ganglion cells after optic nerve transection and a peripheral nerve graft. Neuroreport 23:692-697

Chan KC, Fu QL, Hui ES, So KF, Wu EX (2008) Evaluation of the retina and optic nerve in a rat model of chronic glaucoma using in vivo manganese-enhanced magnetic resonance imaging. NeuroImage 40:1166-1174

Chen SK, Badea TC, Hattar S (2011) Photoentrainment and pupillary light reflex are mediated by distinct populations of ipRGCs. Nature 476:92-95

Choi D, Li D, Raisman G (2002) Fluorescent retrograde neuronal tracers that label the rat facial nucleus: a comparison of Fast Blue, Fluoro-ruby, Fluoro-emerald, Fluoro-Gold and DiI. J Neurosci Methods 117:167-172

Chung K, Deisseroth K (2013) CLARITY for mapping the nervous system. Nat Methods 10:508-513

Cohen BN, Fain GL, Fain MJ (1989) GABA and glycine channels in isolated ganglion cells from the goldfish retina. J Physiol 418:53-82

Cohen A, Bray GM, Aguayo AJ (1994) Neurotrophin-4/5 (NT-4/5) increases adult rat retinal ganglion cell survival and neurite outgrowth in vitro. J Neurobiol 25:953-959

Cook GMW, Jareonsettasin P, Keynes RJ (2014) Growth cone collapse assay. In: Murray AJ (ed) Axon growth and regeneration: methods and protocols. Springer, New York, pp 73-83

Cubillan L, Obregon F, Lima L (2012) Neurites outgrowth and amino acids levels in goldfish retina under hypo-osmotic or hyperosmotic conditions. Int J Dev Neurosci 30:55-61

Cui Q, Harvey AR (2000) CNTF promotes the regrowth of retinal ganglion cell axons into murine peripheral nerve grafts. Neuroreport 11:3999-4002

Cui Q, Lu Q, So KF, Yip HK (1999) CNTF, not other trophic factors, promotes axonal regeneration of axotomized retinal ganglion cells in adult hamsters. Investig Ophthalmol Vis Sci 40:760-766

David S, Aguayo AJ (1981) Axonal elongation into peripheral nervous system "bridges" after central nervous system injury in adult rats. Science 214:931-933

David S, Aguayo AJ (1985) Axonal regeneration after crush injury of rat central nervous system fibres innervating peripheral nerve grafts. J Neurocytol 14:1-12

de Lima S, Koriyama Y, Kurimoto T, Oliveira JT, Yin Y, Li Y, Gilbert HY, Fagiolini M, Martinez AM, Benowitz L (2012) Full-length axon regeneration in the adult mouse optic nerve and partial recovery of simple visual behaviors. Proc Natl Acad Sci USA 109:9149-9154

de la Camara M-F, Olivares-Gonzalez C, Hervas L, Salom D, Millan D, Rodrigo R (2014) Infliximab reduces Zaprinast-induced retinal degeneration in cultures of porcine retina. J Neuroinflammation 11:172

Dezawa M, Nagano T (1993) Contacts between regenerating axons and the Schwann cells of sciatic nerve segments grafted to the optic nerve of adult rats. J Neurocytol 22:1103-1112

Dezawa M, Kawana K, Adachi-Usami E (1997) The role of Schwann cells during retinal ganglion cell regeneration induced by peripheral nerve transplantation. Investig Ophthalmol Vis Sci 38:1401-1410 
Diekmann H, Kalbhen P, Fischer D (2015a) Active mechanistic target of rapamycin plays an ancillary rather than essential role in zebrafish CNS axon regeneration. Front Cell Neurosci 9:251

Diekmann H, Kalbhen P, Fischer D (2015b) Characterization of optic nerve regeneration using transgenic zebrafish. Front Cell Neurosci 9:118

Dodt HU, Leischner U, Schierloh A, Jahrling N, Mauch CP, Deininger K, Deussing JM, Eder M, Zieglgansberger W, Becker K (2007) Ultramicroscopy: three-dimensional visualization of neuronal networks in the whole mouse brain. Nat Methods 4:331-336

Doster SK, Lozano AM, Aguayo AJ, Willard MB (1991) Expression of the growth-associated protein GAP-43 in adult rat retinal ganglion cells following axon injury. Neuron 6:635-647

Dratviman-Storobinsky O, Hasanreisoglu M, Offen D, Barhum Y, Weinberger D, Goldenberg-Cohen N (2008) Progressive damage along the optic nerve following induction of crush injury or rodent anterior ischemic optic neuropathy in transgenic mice. Mol Vis 14:2171-2179

Drescher U, Kremoser C, Handwerker C, Loschinger J, Noda M, Bonhoeffer F (1995) In vitro guidance of retinal ganglion cell axons by RAGS, a $25 \mathrm{kDa}$ tectal protein related to ligands for Eph receptor tyrosine kinases. Cell 82:359-370

Duan X, Qiao M, Bei F, Kim IJ, He Z, Sanes JR (2015) Subtypespecific regeneration of retinal ganglion cells following axotomy: effects of osteopontin and mTOR signaling. Neuron 85:1244-1256

Dumanskaya G, Purnyn H, Rykhal'skii O, Veselovskii N (2011) Primary culture of dissociated cells of the rat retina under conditions of long-lasting culturing: properties of ganglion cells. Neurophysiology 43:321-323

Dunlop SA (2003) Axonal sprouting in the optic nerve is not a prerequisite for successful regeneration. J Comp Neurol 465:319-334

Dunlop SA, Roberts JD, Armstrong KN, Edwards SJ, Reynolds SJ, Thom MD, Beazley LD (1997) Impaired vision for binocular tasks after unilateral optic nerve regeneration in the frog Litoria moorei. Behav Brain Res 84:195-201

Dunlop SA, Tee LB, Stirling RV, Taylor AL, Runham PB, Barber AB, Kuchling G, Rodger J, Roberts JD, Harvey AR, Beazley LD (2004) Failure to restore vision after optic nerve regeneration in reptiles: interspecies variation in response to axotomy. J Comp Neurol 478:292-305

Dunlop SA, Tee LB, Goossens MA, Stirling RV, Hool L, Rodger J, Beazley LD (2007) Regenerating optic axons restore topography after incomplete optic nerve injury. J Comp Neurol 505:46-57

Duprey-Diaz MV, Blagburn JM, Blanco RE (2016) Optic nerve injury upregulates retinoic acid signaling in the adult frog visual system. J Chem Neuroanat 77:80-92

Duvdevani R, Rosner M, Belkin M, Sautter J, Sabel BA, Schwartz M (1990) Graded crush of the rat optic nerve as a brain injury model: combining electrophysiological and behavioral outcome. Restor Neurol Neurosci 2:31-38

Elsaeidi F, Bemben MA, Zhao XF, Goldman D (2014) Jak/Stat signaling stimulates zebrafish optic nerve regeneration and overcomes the inhibitory actions of Socs3 and Sfpq. J Neurosci 34:2632-2644

Erikson KM, John CE, Jones SR, Aschner M (2005) Manganese accumulation in striatum of mice exposed to toxic doses is dependent upon a functional dopamine transporter. Environ Toxicol Pharmacol 20:390-394

Erskine L, Herrera E (2007) The retinal ganglion cell axon's journey: insights into molecular mechanisms of axon guidance. Dev Biol 308:1-14

Erturk A, Becker K, Jahrling N, Mauch CP, Hojer CD, Egen JG, Hellal F, Bradke F, Sheng M, Dodt HU (2012) Three-dimensional imaging of solvent-cleared organs using 3DISCO. Nat Protoc 7:1983-1995
Feigenspan A, Dedek K, Schlich K, Weiler R, Thanos S (2010) Expression and biophysical characterization of voltage-gated sodium channels in axons and growth cones of the regenerating optic nerve. Investig Ophthalmol Vis Sci 51:1789-1799

Filbin MT (2003) Myelin-associated inhibitors of axonal regeneration in the adult mammalian CNS. Nat Rev Neurosci 4:703-713

Fischer D, Leibinger M (2012) Promoting optic nerve regeneration. Prog Retin Eye Res 31:688-701

Fischer D, He Z, Benowitz LI (2004) Counteracting the Nogo receptor enhances optic nerve regeneration if retinal ganglion cells are in an active growth state. J Neurosci 24:1646-1651

Fischer S, Engelmann C, Herrmann KH, Reichenbach JR, Witte OW, Weih F, Kretz A, Haenold R (2014) In vivo imaging of optic nerve fiber integrity by contrast-enhanced MRI in mice. J Vis Exp

Fischer D, Harvey AR, Pernet V, Lemmon VP, Park KK (2017) Optic nerve regeneration in mammals: regenerated or spared axons? Exp Neurol 296:83-88

Fitch MT, Silver J (2008) CNS injury, glial scars, and inflammation: inhibitory extracellular matrices and regeneration failure. Exp Neurol 209:294-301

Fleisch VC, Fraser B, Allison WT (2011) Investigating regeneration and functional integration of CNS neurons: lessons from zebrafish genetics and other fish species. Biochim Biophys Acta 1812:364-380

Ford-Holevinski TS, Hopkins JM, McCoy JP, Agranoff BW (1986) Laminin supports neurite outgrowth from explants of axotomized adult rat retinal neurons. Brain Res 393:121-126

Galindo-Romero C, Valiente-Soriano FJ, Jimenez-Lopez M, GarciaAyuso D, Villegas-Perez MP, Vidal-Sanz M, Agudo-Barriuso M (2013) Effect of brain-derived neurotrophic factor on mouse axotomized retinal ganglion cells and phagocytic microglia. Investig Ophthalmol Vis Sci 54:974-985

Gasparini L, Crowther RA, Martin KR, Berg N, Coleman M, Goedert M, Spillantini MG (2011) Tau inclusions in retinal ganglion cells of human P301S tau transgenic mice: effects on axonal viability. Neurobiol Aging 32:419-433

Gaublomme D, Buyens T, Moons L (2013) Automated analysis of neurite outgrowth in mouse retinal explants. J Biomol Screen 18:534-543

Gaublomme D, Buyens T, De Groef L, Stakenborg M, Janssens E, Ingvarsen S, Porse A, Behrendt N, Moons L (2014) Matrix metalloproteinase 2 and membrane type 1 matrix metalloproteinase co-regulate axonal outgrowth of mouse retinal ganglion cells. J Neurochem 129:966-979

Gaze RM, Grant P (1978) The diencephalic course of regenerating retinotectal fibres in Xenopus tadpoles. J Embryol Exp Morphol 44:201-216

Gaze RM, Jacobson M, Szekely C (1963) The retino-tectal projection in Xenopus with compound eyes. J Physiol 165:484-499

Gaze RM, Keating MJ, Chung SH (1974) The evolution of the retinotectal map during development in Xenopus. Proc R Soc Lond B Biol Sci 185:301-330

Geeraerts E, Moons L, De Groef L (2016) Reaching for the brain: stimulating neural activity as the big leap in optic nerve regeneration. Eye Sci 31(4):221-224

Ghinia MG (2013) Commonly used methods for purification of rare cell populations. Ann Romanian Soc Cell Biol 18:57-64

Glynn D, Bortnick RA, Morton AJ (2003) Complexin II is essential for normal neurological function in mice. Hum Mol Genet 12:2431-2448

Goldberg JL, Barres BA (2000) The relationship between neuronal survival and regeneration. Annu Rev Neurosci 23:579-612

Goldberg JL, Klassen MP, Hua Y, Barres BA (2002) Amacrine-signaled loss of intrinsic axon growth ability by retinal ganglion cells. Science 296:1860-1864 
Goldman D, Hankin M, Li Z, Dai X, Ding J (2001) Transgenic zebrafish for studying nervous system development and regeneration. Transgenic Res 10:21-33

Goritz C, Thiebaut R, Tessier LH, Nieweg K, Moehle C, Buard I, Dupont JL, Schurgers LJ, Schmitz G, Pfrieger FW (2007) Gliainduced neuronal differentiation by transcriptional regulation. Glia 55:1108-1122

Gravel M, Weng YC, Kriz J (2011) Model system for live imaging of neuronal responses to injury and repair. Mol Imaging 10:434-445

Gupta VK, You Y, Li JC, Klistorner A, Graham SL (2013) Protective effects of 7,8-dihydroxyflavone on retinal ganglion and RGC-5 cells against excitotoxic and oxidative stress. J Mol Neurosci 49:96-104

Haenold R, Herrmann KH, Schmidt S, Reichenbach JR, Schmidt KF, Lowel S, Witte OW, Weih F, Kretz A (2012) Magnetic resonance imaging of the mouse visual pathway for in vivo studies of degeneration and regeneration in the CNS. NeuroImage 59:363-376

Heiduschka P, Romann I, Stieglitz T, Thanos S (2001) Perforated microelectrode arrays implanted in the regenerating adult central nervous system. Exp Neurol 171:1-10

Hellstrom M, Pollett MA, Harvey AR (2011) Post-injury delivery of rAAV2-CNTF combined with short-term pharmacotherapy is neuroprotective and promotes extensive axonal regeneration after optic nerve trauma. J Neurotrauma 28:2475-2483

Hieber V, Dai X, Foreman M, Goldman D (1998) Induction of a1-tubulin gene expression during development and regeneration of the fish central nervous system. J Neurobiol 37:429-440

Hoff A, Hammerle H, Schlosshauer B (1999) Organotypic culture system of chicken retina. Brain Res Brain Res Protoc 4:237-248

Hong S, Iizuka Y, Kim CY, Seong GJ (2012) Isolation of primary mouse retinal ganglion cells using immunopanning-magnetic separation. Mol Vis 18:2922-2930

Hong S, Iizuka Y, Lee T, Kim CY, Seong GJ (2014) Neuroprotective and neurite outgrowth effects of maltol on retinal ganglion cells under oxidative stress. Mol Vis 20:1456-1462

Huang YY, Neuhauss SC (2008) The optokinetic response in zebrafish and its applications. Front Biosci 13:1899-1916

Humphrey MF, Beazley LD (1985) Retinal ganglion cell death during optic nerve regeneration in the frog Hyla moorei. J Comp Neurol 236:382-402

Inatani M, Honjo M, Otori Y, Oohira A, Kido N, Tano Y, Honda Y, Tanihara H (2001) Inhibitory effects of neurocan and phosphacan on neurite outgrowth from retinal ganglion cells in culture. Investig Ophthalmol Vis Sci 42:1930-1938

Inoue T, Sasaki H, Hosokawa M, Fukuda Y (2000) Axonal regeneration of mouse retinal ganglion cells by peripheral nerve transplantation; a quantitative study. Restor Neurol Neurosci 17:23-29

Inoue T, Hosokawa M, Morigiwa K, Ohashi Y, Fukuda Y (2002) Bcl-2 overexpression does not enhance in vivo axonal regeneration of retinal ganglion cells after peripheral nerve transplantation in adult mice. J Neurosci 22:4468-4477

Ivanov D, Dvoriantchikova G, Barakat DJ, Nathanson L, Shestopalov VI (2008) Differential gene expression profiling of large and small retinal ganglion cells. J Neurosci Methods 174:10-17

Jeffrey BG, McGill TJ, Haley TL, Morgans CW, Duvoisin RM (2011) Anatomical, physiological, and behavioral analysis of rodent vision. In: Raber J (ed) Animal models of behavioral analysis. Humana Press, Totowa, pp 29-54

Johnson TV, Oglesby EN, Steinhart MR, Cone-Kimball E, Jefferys J, Quigley HA (2016) Time-lapse retinal ganglion cell dendritic field degeneration imaged in organotypic retinal explant culture. Investig Ophthalmol Vis Sci 57:253-264

Kalesnykas G, Oglesby EN, Zack DJ, Cone FE, Steinhart MR, Tian J, Pease ME, Quigley HA (2012) Retinal ganglion cell morphology after optic nerve crush and experimental glaucoma. Investig Ophthalmol Vis Sci 53:3847-3857

Kammen A, Law M, Tjan BS, Toga AW, Shi Y (2016) Automated retinofugal visual pathway reconstruction with multi-shell HARDI and FOD-based analysis. NeuroImage 125:767-779

Kaneda M, Nagashima M, Nunome T, Muramatsu T, Yamada Y, Kubo M, Muramoto K, Matsukawa T, Koriyama Y, Sugitani K, Vachkov IH, Mawatari K, Kato S (2008) Changes of phosphogrowth-associated protein 43 (phospho-GAP43) in the zebrafish retina after optic nerve injury: a long-term observation. Neurosci Res 61:281-288

Kato S, Matsukawa T, Koriyama Y, Sugitani K, Ogai K (2013) A molecular mechanism of optic nerve regeneration in fish: the retinoid signaling pathway. Prog Retin Eye Res 37:13-30

Ke MT, Fujimoto S, Imai T (2013) SeeDB: a simple and morphologypreserving optical clearing agent for neuronal circuit reconstruction. Nat Neurosci 16:1154-1161

Keating MJ, Gaze RM (1970) The ipsilateral retinotectal pathway in the frog. Q J Exp Physiol Cogn Med Sci 55:284-292

Knoll B, Weinl C, Nordheim A, Bonhoeffer F (2007) Stripe assay to examine axonal guidance and cell migration. Nat Protoc $2: 1216-1224$

Koechling T, Khalique H, Sundstrom E, Avila J, Lim F (2011) A culture model for neurite regeneration of human spinal cord neurons. J Neurosci Methods 201:346-354

Koriyama Y, Takagi Y, Chiba K, Yamazaki M, Arai K, Matsukawa T, Suzuki H, Sugitani K, Kagechika H, Kato S (2011) Neuritogenic activity of a genipin derivative in retinal ganglion cells is mediated by retinoic acid receptor beta expression through nitric oxide/S-nitrosylation signaling. J Neurochem 119:1232-1242

Krishnamoorthy RR, Clark AF, Daudt D, Vishwanatha JK, Yorio T (2013) A forensic path to RGC-5 cell line identification: lessons learned. Investig Ophthalmol Vis Sci 54:5712-5719

Kurimoto T, Yin Y, Omura K, Gilbert HY, Kim D, Cen LP, Moko L, Kugler S, Benowitz LI (2010) Long-distance axon regeneration in the mature optic nerve: contributions of oncomodulin, cAMP, and pten gene deletion. J Neurosci 30:15654-15663

Kurimoto T, Yin Y, Habboub G, Gilbert HY, Li Y, Nakao S, HafeziMoghadam A, Benowitz LI (2013) Neutrophils express oncomodulin and promote optic nerve regeneration. J Neurosci 33:14816-14824

Kusik BW, Hammond DR, Udvadia AJ (2010) Transcriptional regulatory regions of gap43 needed in developing and regenerating retinal ganglion cells. Dev Dyn 239:482-495

Lagreze WA, Pielen A, Steingart R, Schlunck G, Hofmann HD, Gozes I, Kirsch M (2005) The peptides ADNF-9 and NAP increase survival and neurite outgrowth of rat retinal ganglion cells in vitro. Investig Ophthalmol Vis Sci 46:933-938

Le Bihan D, Mangin JF, Poupon C, Clark CA, Pappata S, Molko N, Chabriat H (2001) Diffusion tensor imaging: concepts and applications. J Magn Reson Imaging 13:534-546

Lee E, Kim HJ, Sun W (2016) See-through technology for biological tissue: 3-dimensional visualization of macromolecules. Int Neurourol J 20:S15-S22

Leibinger M, Andreadaki A, Gobrecht P, Levin E, Diekmann H, Fischer D (2016) Boosting central nervous system axon regeneration by circumventing limitations of natural cytokine signaling. Mol Ther 24:1712-1725

Lemmens K, Bollaerts I, Bhumika S, De Groef L, Van houcke J, Darras VM, Van Hove I, Moons L (2015) Matrix metalloproteinases as promising regulators of axonal regrowth in the injured adult zebrafish retinotectal system. J Comp Neurol 524:1472-1493

Lemmens K, Hove IV, Moons L (2016) Complementary research in mammals and fish indicates MMP-2 as a pleiotropic contributor to optic nerve regeneration. Neural Regener Res 11:740-742 
Leon S, Yin Y, Nguyen J, Irwin N, Benowitz LI (2000) Lens injury stimulates axon regeneration in the mature rat optic nerve. J Neurosci 20:4615-4626

Li L (2001) Zebrafish mutants: behavioral genetic studies of visual system defects. Dev Dyn 221:365-372

Li S, He Q, Wang H, Tang X, Ho KW, Gao X, Zhang Q, Shen Y, Cheung A, Wong F, Wong YH, Ip NY, Jiang L, Yung WH, Liu K (2015) Injured adult retinal axons with Pten and Socs 3 codeletion reform active synapses with suprachiasmatic neurons. Neurobiol Dis 73:366-376

Lim JH, Stafford BK, Nguyen PL, Lien BV, Wang C, Zukor K, He Z, Huberman AD (2016) Neural activity promotes long-distance, target-specific regeneration of adult retinal axons. Nat Neurosci 19:1073-1084

Lindsey AE, Powers MK (2007) Visual behavior of adult goldfish with regenerating retina. Vis Neurosci 24:247-255

Lindsey JD, Duong-Polk KX, Dai Y, Nguyen DH, Leung CK, Weinreb RN (2013) Protection by an oral disubstituted hydroxylamine derivative against loss of retinal ganglion cell differentiation following optic nerve crush. PLoS One 8:e65966

Liu X, Hawkes E, Ishimaru T, Tran T, Sretavan DW (2006) EphB3: an endogenous mediator of adult axonal plasticity and regrowth after CNS injury. J Neurosci 26:3087-3101

Liu Y, Yu H, Deaton SK, Szaro BG (2012) Heterogeneous nuclear ribonucleoprotein $\mathrm{K}$, an RNA-binding protein, is required for optic axon regeneration in Xenopus laevis. J Neurosci 32:3563-3574

Logan A, Ahmed Z, Baird A, Gonzalez AM, Berry M (2006) Neurotrophic factor synergy is required for neuronal survival and disinhibited axon regeneration after CNS injury. Brain 129:490-502

London A, Benhar I, Schwartz M (2013) The retina as a window to the brain-from eye research to CNS disorders. Nat Rev Neurol 9:44-53

Lorber B, Berry M, Douglas MR, Nakazawa T, Logan A (2009) Activated retinal glia promote neurite outgrowth of retinal ganglion cells via apolipoprotein E. J Neurosci Res 87:2645-2652

Lorber B, Guidi A, Fawcett JW, Martin KR (2012) Activated retinal glia mediated axon regeneration in experimental glaucoma. Neurobiol Dis 45:243-252

Luo X, Heidinger V, Picaud S, Lambrou G, Dreyfus H, Sahel J, Hicks D (2001) Selective excitotoxic degeneration of adult pig retinal ganglion cells in vitro. Investig Ophthalmol Vis Sci 42:1096-1106

Luo X, Salgueiro Y, Beckerman SR, Lemmon VP, Tsoulfas P, Park KK (2013) Three-dimensional evaluation of retinal ganglion cell axon regeneration and pathfinding in whole mouse tissue after injury. Exp Neurol 247:653-662

Luo X, Yungher B, Park KK (2014) Application of tissue clearing and light sheet fluorescence microscopy to assess optic nerve regeneration in unsectioned tissues. Methods Mol Biol 1162:209-217

Maaswinkel H, Li L (2003) Spatio-temporal frequency characteristics of the optomotor response in zebrafish. Vis Res 43:21-30

Matsukawa T, Arai K, Koriyama Y, Liu Z, Kato S (2004) Axonal regeneration of fish optic nerve after injury. Biol Pharm Bull 27:445-451

Maturana HR, Lettvin JY, McCulloch WS, Pitts WH (1959) Evidence that cut optic nerve fibers in a frog regenerate to their proper places in the tectum. Science 130:1709-1710

McCurley AT, Callard GV (2010) Time course analysis of gene expression patterns in zebrafish eye during optic nerve regeneration. $\mathrm{J}$ Exp Neurosci 2010:17-33

McDowell AL, Dixon LJ, Houchins JD, Bilotta J (2004) Visual processing of the zebrafish optic tectum before and after optic nerve damage. Vis Neurosci 21:97-106

Meyer RL, Kageyama GH (1999) Large-scale synaptic errors during map formation by regeneration optic axons in the goldfish. J Comp Neurol 409:299-312
Miyake K, Yoshida M, Inoue Y, Hata Y (2007) Neuroprotective effect of transcorneal electrical stimulation on the acute phase of optic nerve injury. Investig Ophthalmol Vis Sci 48:2356-2361

Monnier PP, Sierra A, Macchi P, Deitinghoff L, Andersen JS, Mann M, Flad M, Hornberger MR, Stahl B, Bonhoeffer F, Mueller BK (2002) RGM is a repulsive guidance molecule for retinal axons. Nature 419:392-395

Monnier PP, Sierra A, Schwab JM, Henke-Fahle S, Mueller BK (2003) The Rho/ROCK pathway mediates neurite growth-inhibitory activity associated with the chondroitin sulfate proteoglycans of the CNS glial scar. Mol Cell Neurosci 22:319-330

Morgan-Warren PJ, O’Neill J, de Cogan F, Spivak I, Ashush H, Kalinski H, Ahmed Z, Berry M, Feinstein E, Scott RA, Logan A (2016) siRNA-mediated knockdown of the mTOR inhibitor RTP801 promotes retinal ganglion cell survival and axon elongation by direct and indirect mechanisms. Investig Ophthalmol Vis Sci 57:429-443

Mueller KP, Neuhauss SC (2010) Quantitative measurements of the optokinetic response in adult fish. J Neurosci Methods 186:29-34

Muller A, Hauk TG, Fischer D (2007) Astrocyte-derived CNTF switches mature RGCs to a regenerative state following inflammatory stimulation. Brain 130:3308-3320

Munzel EJ, Becker CG, Becker T, Williams A (2014) Zebrafish regenerate full thickness optic nerve myelin after demyelination, but this fails with increasing age. Acta Neuropathol Commun 2:77

Nadal-Nicolas FM, Salinas-Navarro M, Vidal-Sanz M, Agudo-Barriuso M (2015a) Two methods to trace retinal ganglion cells with fluorogold: from the intact optic nerve or by stereotactic injection into the optic tract. Exp Eye Res 131:12-19

Nadal-Nicolas FM, Sobrado-Calvo P, Jimenez-Lopez M, Vidal-Sanz M, Agudo-Barriuso M (2015b) Long-term effect of optic nerve axotomy on the retinal ganglion cell layer. Investig Ophthalmol Vis Sci 56:6095-6112

Narita K, Kawasaki F, Kita H (1990) Mn and Mg influxes through Ca channels of motor nerve terminals are prevented by verapamil in frogs. Brain Res 510:289-295

Neugebauer KM, Tomaselli KJ, Lilien J, Reichardt LF (1988) N-cadherin, NCAM, and integrins promote retinal neurite outgrowth on astrocytes in vitro. J Cell Biol 107:1177-1187

Neuhauss SC (2003) Behavioral genetic approaches to visual system development and function in zebrafish. J Neurobiol 54:148-160

$\mathrm{Ng} \mathrm{TF}$, So KF, Chung SK (1995) Influence of peripheral nerve grafts on the expression of GAP-43 in regenerating retinal ganglion cells in adult hamsters. J Neurocytol 24:487-496

Nona S (1995) Regeneration in the goldfish visual System. In: Kolb H, Fernandez E, Nelson R (eds) Webvision: the organization of the retina and visual system. University of Utah, Salt Lake City

Northmore DP (1989a) Quantitative electrophysiological studies of regenerating visuotopic maps in goldfish-I. Early recovery of dimming sensitivity in tectum and torus longitudinalis. Neuroscience 32:739-747

Northmore DP (1989b) Quantitative electrophysiological studies of regenerating visuotopic maps in goldfish-II. Delayed recovery of sensitivity to small light flashes. Neuroscience 32:749-757

Nusetti S, Obregon F, Quintal M, Benzo Z, Lima L (2005) Taurine and zinc modulate outgrowth from goldfish retinal explants. Neurochem Res 30:1483-1492

Ogai K, Kuwana A, Hisano S, Nagashima M, Koriyama Y, Sugitani K, Mawatari K, Nakashima H, Kato S (2014) Upregulation of leukemia inhibitory factor (LIF) during the early stage of optic nerve regeneration in zebrafish. PLoS One 9:e106010

Okada T, Ichikawa M, Tokita Y, Horie H, Saito K, Yoshida J, Watanabe M (2005) Intravitreal macrophage activation enables cat retinal ganglion cells to regenerate injured axons into the mature optic nerve. Exp Neurol 196:153-163 
Ou YT, Lu MS, Chiao CC (2012) The effects of electrical stimulation on neurite outgrowth of goldfish retinal explants. Brain Res 1480:22-29

Park KK, Liu K, Hu Y, Smith PD, Wang C, Cai B, Xu B, Connolly L, Kramvis I, Sahin M, He Z (2008) Promoting axon regeneration in the adult CNS by modulation of the PTEN/mTOR pathway. Science 322:963-966

Paschon V, Higa GS, Walter LT, Sousa E, Zuzarte FC, Weber VR, Resende RR, Kihara AH (2013) A new and reliable guide for studies of neuronal loss based on focal lesions and combinations of in vivo and in vitro approaches. PLoS One 8:e60486

Pernet V, Schwab ME (2014) Lost in the jungle: new hurdles for optic nerve axon regeneration. Trends Neurosci 37:381-387

Pernet V, Joly S, Dalkara D, Jordi N, Schwarz O, Christ F, Schaffer DV, Flannery JG, Schwab ME (2013a) Long-distance axonal regeneration induced by CNTF gene transfer is impaired by axonal misguidance in the injured adult optic nerve. Neurobiol Dis 51:202-213

Pernet V, Joly S, Jordi N, Dalkara D, Guzik-Kornacka A, Flannery JG, Schwab ME (2013b) Misguidance and modulation of axonal regeneration by Stat 3 and Rho/ROCK signaling in the transparent optic nerve. Cell Death Dis 4:e734

Pinto LH, Enroth-Cugell C (2000) Tests of the mouse visual system. Mamm Genome 11:531-536

Prusky GT, Alam NM, Beekman S, Douglas RM (2004) Rapid quantification of adult and developing mouse spatial vision using a virtual optomotor system. Investig Ophthalmol Vis Sci 45:4611-4616

Quigley HA, Nickells RW, Kerrigan LA, Pease ME, Thibault DJ, Zack DJ (1995) Retinal ganglion cell death in experimental glaucoma and after axotomy occurs by apoptosis. Invest Ophthalmol Vis Sci 36:774-786

Ramón y Cajal, S, May RM (1928) Degeneration and regeneration of the nervous system. Oxford University Press, Oxford

Rasmussen JP, Sagasti A (2016) Learning to swim, again: axon regeneration in fish. Exp Neurol 318-330

Renier N, Wu Z, Simon DJ, Yang J, Ariel P, Tessier-Lavigne M (2014) iDISCO: a simple, rapid method to immunolabel large tissue samples for volume imaging. Cell 159:896-910

Richardson PM, McGuinness UM, Aguayo AJ (1980) Axons from CNS neurons regenerate into PNS grafts. Nature 284:264-265

Richardson PM, Issa VM, Aguayo AJ (1984) Regeneration of long spinal axons in the rat. J Neurocytol 13:165-182

Ruzafa N, Vecino E (2015) Effect of Muller cells on the survival and neuritogenesis in retinal ganglion cells. Archivos de la Sociedad Espanola de Oftalmologia 90:522-526

Ryu S, Brown SL, Kolozsvary A, Ewing JR, Kim JH (2002) Noninvasive detection of radiation-induced optic neuropathy by manganese-enhanced MRI. Radiat Res 157:500-505

Sagawa H, Terasaki H, Nakamura M, Ichikawa M, Yata T, Tokita Y, Watanabe M (2007) A novel ROCK inhibitor, Y-39983, promotes regeneration of crushed axons of retinal ganglion cells into the optic nerve of adult cats. Exp Neurol 205:230-240

Sandvig I, Sandvig A (2014) Using manganese-enhanced MRI to assess optic nerve regeneration. Methods Mol Biol 1162:233-249

Sandvig I, Thuen M, Hoang L, Olsen O, Sardella TC, Brekken C, Tvedt KE, Barnett SC, Haraldseth O, Berry M, Sandvig A (2012) In vivo MRI of olfactory ensheathing cell grafts and regenerating axons in transplant mediated repair of the adult rat optic nerve. NMR Biomed 25:620-631

Sapieha PS, Peltier M, Rendahl KG, Manning WC, Di Polo A (2003) Fibroblast growth factor-2 gene delivery stimulates axon growth by adult retinal ganglion cells after acute optic nerve injury. Mol Cell Neurosci 24:656-672
Sautter J, Schwartz M, Duvdevani R, Sabel BA (1991) GM1 ganglioside treatment reduces visual deficits after graded crush of the rat optic nerve. Brain Res 565:23-33

Sauve Y, Sawai H, Rasminsky M (1995) Functional synaptic connections made by regenerated retinal ganglion cell axons in the superior colliculus of adult hamsters. J Neurosci 15:665-675

Schwab ME, Caroni P (1988) Oligodendrocytes and CNS myelin are nonpermissive substrates for neurite growth and fibroblast spreading in vitro. J Neurosci 8:2381-2393

Schwab ME, Thoenen H (1985) Dissociated neurons regenerate into sciatic but not optic nerve explants in culture irrespective of neurotrophic factors. J Neurosci 5:2415-2423

Schwalb JM, Boulis NM, Gu MF, Winickoff J, Jackson PS, Irwin N, Benowitz LI (1995) Two factors secreted by the goldfish optic nerve induce retinal ganglion cells to regenerate axons in culture. J Neurosci 15:5514-5525

Seigel GM (2014) Review: R28 retinal precursor cells: the first 20 years. Mol Vis 20:301-306

Shang C, Liu Z, Chen Z, Shi Y, Wang Q, Liu S, Li D, Cao P (2015) A parvalbumin-positive excitatory visual pathway to trigger fear responses in mice. Science 348:1472-1477

Sharma TP, Liu Y, Wordinger RJ, Pang IH, Clark AF (2015) Neuritin 1 promotes retinal ganglion cell survival and axonal regeneration following optic nerve crush. Cell Death Dis 6:e1661

Shirazi Fard S, Blixt M, Hallbook F (2015) Whole retinal explants from chicken embryos for electroporation and chemical reagent treatments. J Vis Exp 103:53202

Shum JW, Liu K, So KF (2016) The progress in optic nerve regeneration, where are we? Neural Regener Res 11:32-36

Silver J, Miller JH (2004) Regeneration beyond the glial scar. Nat Rev Neurosci 5:146-156

Singman EL, Scalia F (1991) Quantitative study of the tectally projecting retinal ganglion cells in the adult frog. II. Cell survival and functional recovery after optic nerve transection. J Comp Neurol 307:351-369

Sippl C, Tamm ER (2014) What is the nature of the RGC-5 cell line? Adv Exp Med Biol 801:145-154

Smith PD, Sun F, Park KK, Cai B, Wang C, Kuwako K, MartinezCarrasco I, Connolly L, He Z (2009) SOCS3 deletion promotes optic nerve regeneration in vivo. Neuron 64:617-623

So KF, Aguayo AJ (1985) Lengthy regrowth of cut axons from ganglion cells after peripheral nerve transplantation into the retina of adult rats. Brain Res 328:349-354

Soto I, Marie B, Baro DJ, Blanco RE (2003) FGF-2 modulates expression and distribution of GAP-43 in frog retinal ganglion cells after optic nerve injury. J Neurosci Res 73:507-517

Sperry RW (1948) Patterning of central synapses in regeneration of the optic nerve in teleosts. Physiol Zool 21:351-361

Steketee MB, Oboudiyat C, Daneman R, Trakhtenberg E, Lamoureux P, Weinstein JE, Heidemann S, Barres BA, Goldberg JL (2014) Regulation of intrinsic axon growth ability at retinal ganglion cell growth cones. Investig Ophthalmol Vis Sci 55:4369-4377

Stirling RV, Dunlop SA, Beazley LD (1998) An in vitro technique for electrophysiological mapping of reptilian retinotectal projections. J Neurosci Methods 81:85-89

Stirling RV, Dunlop SA, Beazley LD (1999) Electrophysiological evidence for transient topographic organization of retinotectal projections during optic nerve regeneration in the lizard, Ctenophorus ornatus. Vis Neurosci 16:681-693

Sugitani K, Koriyama Y, Ogai K, Wakasugi K, Kato S (2016) A possible role of neuroglobin in the retina after optic nerve injury: a comparative study of zebrafish and mouse retina. Adv Exp Med Biol 854:671-675

Sun F, He Z (2010) Neuronal intrinsic barriers for axon regeneration in the adult CNS. Curr Opin Neurobiol 20:510-518 
Sun SW, Liang HF, Cross AH, Song SK (2008) Evolving Wallerian degeneration after transient retinal ischemia in mice characterized by diffusion tensor imaging. NeuroImage 40:1-10

Sun F, Park KK, Belin S, Wang D, Lu T, Chen G, Zhang K, Yeung C, Feng G, Yankner BA, He Z (2011) Sustained axon regeneration induced by co-deletion of PTEN and SOCS3. Nature 480:372-375

Sun LO, Brady CM, Cahill H, Al-Khindi T, Sakuta H, Dhande OS, Noda M, Huberman AD, Nathans J, Kolodkin AL (2015) Functional assembly of accessory optic system circuitry critical for compensatory eye movements. Neuron 86:971-984

Surgucheva I, Weisman AD, Goldberg JL, Shnyra A, Surguchov A (2008) Gamma-synuclein as a marker of retinal ganglion cells. Mol Vis 14:1540-1548

Tappeiner C, Gerber S, Enzmann V, Balmer J, Jazwinska A, Tschopp M (2012) Visual acuity and contrast sensitivity of adult zebrafish. Front Zool 9:10

Taylor L, Arner K, Taylor IH, Ghosh F (2014) Feet on the ground: physical support of the inner retina is a strong determinant for cell survival and structural preservation in vitro. Investig Ophthalmol Vis Sci 55:2200-2213

Thangaraj G, Greif A, Layer PG (2011) Simple explant culture of the embryonic chicken retina with long-term preservation of photoreceptors. Exp Eye Res 93:556-564

Thanos S, Vidal-Sanz M, Aguayo AJ (1987) The use of rhodamine-Bisothiocyanate (RITC) as an anterograde and retrograde tracer in the adult rat visual system. Brain Res 406:317-321

Thanos S, Vanselow J, Mey J (1992) Ganglion cells in the juvenile chick retina and their ability to regenerate axons in vitro. Exp Eye Res 54:377-391

Thanos S, Naskar R, Heiduschka P (1997) Regenerating ganglion cell axons in the adult rat establish retinofugal topography and restore visual function. Exp Brain Res 114:483-491

Thuen M, Singstad TE, Pedersen TB, Haraldseth O, Berry M, Sandvig A, Brekken C (2005) Manganese-enhanced MRI of the optic visual pathway and optic nerve injury in adult rats. J Magn Reson Imaging 22:492-500

Thuen M, Berry M, Pedersen TB, Goa PE, Summerfield M, Haraldseth O, Sandvig A, Brekken C (2008) Manganese-enhanced MRI of the rat visual pathway: acute neural toxicity, contrast enhancement, axon resolution, axonal transport, and clearance of Mn(2+). J Magn Reson Imaging 28:855-865

Thuen M, Olsen O, Berry M, Pedersen TB, Kristoffersen A, Haraldseth O, Sandvig A, Brekken C (2009) Combination of Mn(2+)enhanced and diffusion tensor MR imaging gives complementary information about injury and regeneration in the adult rat optic nerve. J Magn Reson Imaging 29:39-51

Toops KA, Hagemann TL, Messing A, Nickells RW (2012) The effect of glial fibrillary acidic protein expression on neurite outgrowth from retinal explants in a permissive environment. BMC Res Notes 5:693

Tsai RK, Wang HZ, Sheu MM (1998) Capability of neurite regeneration of retinal explant from adult rat after optic nerve injury. Kaohsiung J Med Sci 14:274-279

Udvadia AJ (2008) $3.6 \mathrm{~kb}$ genomic sequence from Takifugu capable of promoting axon growth-associated gene expression in developing and regenerating zebrafish neurons. Gene Express Patterns 8:382-388

Urban DJ, Roth BL (2015) DREADDs (designer receptors exclusively activated by designer drugs): chemogenetic tools with therapeutic utility. Annu Rev Pharmacol Toxicol 55:399-417

Van Hove I, Lefevere E, Moons L (2015) ROCK inhibition as a novel potential strategy for axonal regeneration in optic neuropathies. Neural Regener Res 10:1949-1950

Van houcke J, Bollaerts I, Geeraerts E, Davis B, Beckers A, Van Hove I, Lemmens K, De Groef L, Moons L (2017) Successful optic nerve regeneration in the senescent zebrafish despite age-related decline of cell intrinsic and extrinsic response processes. Neurobiol Aging 60:1-10

Van de Velde S, De Groef L, Stalmans I, Moons L, Van Hove I (2015) Towards axonal regeneration and neuroprotection in glaucoma: rho kinase inhibitors as promising therapeutics. Prog Neurobiol 131:105-119

Vecino E, Heller JP, Veiga-Crespo P, Martin KR, Fawcett JW (2015) Influence of extracellular matrix components on the expression of integrins and regeneration of adult retinal ganglion cells. PLoS One 10:e125250

Veldman MB, Bemben MA, Thompson RC, Goldman D (2007) Gene expression analysis of zebrafish retinal ganglion cells during optic nerve regeneration identifies KLF6a and KLF7a as important regulators of axon regeneration. Dev Biol 312:596-612

Veldman MB, Bemben MA, Goldman D (2010) Tuba1a gene expression is regulated by KLF6/7 and is necessary for CNS development and regeneration in zebrafish. Mol Cell Neurosci 43:370-383

Vidal-Sanz M, Bray GM, Villegas-Perez MP, Thanos S, Aguayo AJ (1987) Axonal regeneration and synapse formation in the superior colliculus by retinal ganglion cells in the adult rat. J Neurosci 7:2894-2909

Vidal-Sanz M, Bray GM, Aguayo AJ (1991) Regenerated synapses persist in the superior colliculus after the regrowth of retinal ganglion cell axons. J Neurocytol 20:940-952

Wang J, Kolomeyer AM, Zarbin MA, Townes-Anderson E (2011) Organotypic culture of full-thickness adult porcine retina. J Vis Exp

Watanabe M, Sawai H, Fukuda Y (1997) Survival of axotomized retinal ganglion cells in adult mammals. Clin Neurosci 4:233-239

Wehrwein E, Thompson SA, Coulibaly SF, Linn DM, Linn CL (2004) Acetylcholine protection of adult pig retinal ganglion cells from glutamate-induced excitotoxicity. Investig Ophthalmol Vis Sci 45:1531-1543

Welte C, Engel S, Stuermer CA (2015) Upregulation of the zebrafish Nogo-A homologue, Rtn4b, in retinal ganglion cells is functionally involved in axon regeneration. Neural Dev 10:6

Williams RR, Venkatesh I, Pearse DD, Udvadia AJ, Bunge MB (2015) MASH1/Ascl1a leads to GAP43 expression and axon regeneration in the adult CNS. PLoS One 10:e0118918

Willshaw DJ, Fawcett JW, Gaze RM (1983) The visuotectal projections made by Xenopus 'pie slice' compound eyes. J Embryol Exp Morphol 74:29-45

Wu DY, Zheng JQ, McDonald MA, Chang B, Twiss JL (2003) PKC isozymes in the enhanced regrowth of retinal neurites after optic nerve injury. Investig Ophthalmol Vis Sci 44:2783-2790

Xu Z, Jiang F, Zeng Y, Alkhodari HT, Chen F (2011) Culture of rat retinal ganglion cells. J Huazhong Univ Sci Technol Med Sci 31:400-403

Xue T, Do MT, Riccio A, Jiang Z, Hsieh J, Wang HC, Merbs SL, Welsbie DS, Yoshioka T, Weissgerber P, Stolz S, Flockerzi V, Freichel M, Simon MI, Clapham DE, Yau KW (2011) Melanopsin signalling in mammalian iris and retina. Nature 479:67-73

Yanagihara D, Watanabe S, Takagi S, Mitarai G (1993) Neuroanatomical substrate for the dorsal light response. II. Effects of kainic acid-induced lesions of the valvula cerebelli on the goldfish dorsal light response. Neurosci Res 16:33-37

Yang J, Li Q, Wang M, Cao X, Ding Y, Wang G, Liao C (2016) Semiquantitative assessment of optic nerve injury using manganeseenhanced MRI. Jpn J Radiol 34:356-365

Yazejian B, Fain GL (1993) Whole-cell currents activated at nicotinic acetylcholine receptors on ganglion cells isolated from goldfish retina. Vis Neurosci 10:353-361

Yilmaz M, Meister M (2013) Rapid innate defensive responses of mice to looming visual stimuli. Curr Biol 23:2011-2015 
Yoles E, Belkin M, Schwartz M (1996) HU-211, a nonpsychotropic cannabinoid, produces short- and long-term neuroprotection after optic nerve axotomy. J Neurotrauma 13:49-57

Yoshida T, Takeuchi M (1991) Expression of fibronectin and laminin by different types of mouse glial cells cultured in a serum-free medium. Cytotechnology 7:187-196

Yukita M, Machida S, Nishiguchi KM, Tsuda S, Yokoyama Y, Yasuda M, Maruyama K, Nakazawa T (2015) Molecular, anatomical and functional changes in the retinal ganglion cells after optic nerve crush in mice. Doc Ophthalmol Adv Ophthalmol 130:149-156

Yungher BJ, Luo X, Salgueiro Y, Blackmore MG, Park KK (2015) Viral vector-based improvement of optic nerve regeneration: characterization of individual axons' growth patterns and synaptogenesis in a visual target. Gene Ther 22:811-821
Zhang SS, Fu XY, Barnstable CJ (2002) Tissue culture studies of retinal development. Methods 28:439-447

Zhang XM, Li Liu DT, Chiang SW, Choy KW, Pang CP, Lam DS, Yam GH (2010) Immunopanning purification and long-term culture of human retinal ganglion cells. Mol Vis 16:2867-2872

Zhao X, Liu M, Cang J (2014) Visual cortex modulates the magnitude but not the selectivity of looming-evoked responses in the superior colliculus of awake mice. Neuron 84:202-213

Zou S, Tian C, Ge S, Hu B (2013) Neurogenesis of retinal ganglion cells is not essential to visual functional recovery after optic nerve injury in adult zebrafish. PLoS One 8:e57280

Zou SQ, Tian C, Du ST, Hu B (2014) Retrograde labeling of retinal ganglion cells in adult zebrafish with fluorescent dyes. J Vis Exp 